\title{
Petrological and Geochemical Constraints on the
}

\section{Evolution of El-Kahfa Alkaline Ring Complex, South Eastern Desert, Egypt}

\author{
A. M. Bishady ${ }^{1}$, A. M. El-Sherif ${ }^{2}$ and M. E. Darwish ${ }^{2}$ \\ 1. Geol. Dept., Fac. Sci., Menoufiya Univ., Shebin El-Kom, Egypt \\ 2. Nuclear Materials Authority, Cairo, Post Office Box No. 530 Maadi, Egypt
}

\begin{abstract}
El-Kahfa complex locates at the intersection of Lat. 24 $4^{\prime} 18^{\prime \prime} \mathrm{N}$ and Long. $34^{\circ} 38^{\prime} 55^{\prime \prime}$ E, South Eastern Desert of Egypt. It comprises an outer ring composed of alkaline syenites, ranging from barren- to quartz-bearing syenites, an inner ring which varies in composition from leucocratic to melanocratic syenites, and a central stock formed essentially of alkali gabbros. These alkali gabbros are cut by small bodies of alkaline syenites, which occasionally grade into nepheline syenites. The country rocks are represented mainly by metavolcanics and epidiorites. El-Kahfa syenites lack any primary hydrous mafic silicates indicating that their magma was anhydrous. Major and trace elements geochemistry of El-Kahfa rocks reflects the crystallization of early plagioclase followed by Fe-Ti oxides. Salic members in the complex are co-magmatic and related to crystal liquid fractionation. The REE (rare earth elements)'s tetrad is obvious on the primitive mantle normalized pattern of El-Kahfa rocks. The M-type tetrads clearly appear in the more evolved rocks. These tetrad effects are either a feature of magma-fluid system before crystallization or inherited from external fluid during or after the emplacement of the magma. Generally, El-Kahfa rocks parental magma was probably derived from Nb-enriched or at least under-plate mantle source within the continental East-Africa rift zone, where it may be subjected to minor contamination through their fractional crystallization.
\end{abstract}

Key words: Ring complex, El-Kahfa, tetrad effect, South Eastern Desert.

\section{Introduction}

Hunting Geology and Geophysics [1] introduced for the first time El-Kahfa as a ring complex. It is located at the intersection of Lat. $24^{\circ} 8^{\prime} 18^{\prime \prime} \mathrm{N}$ and Long. $34^{\circ} 38^{\prime} 55^{\prime \prime} \mathrm{E}$, with its peak rising 1,018 $\mathrm{m}$ above sea level.

Lockwood [2] surveyed a segment of Egypt including El-Kahfa area magnetically and radiometrically and revealed a radioactive anomaly that attains an amplitude of $200 \mathrm{cps}$.

El-Ramly et al. [3, 4] and El-Ramly and Hussein [5, 6] gave some details about the geology and petrography of El-Kahfa ring complex. They grouped the Egyptian ring complexes into five groups on the basis of their magmatic differentiation and the degree

Corresponding author: Ahmed Bishady, professor, research fields: mineralogy and petrology. of development of the ring nature in addition to the complexity of their structure. El-Kahfa ring complex is encountered in a variety characterized by well-defined ring structure, wide range of rock types and the occurrence of nepheline.

The genesis of this ring complex had been discussed in association with the other Egyptian and African ring complexes by several workers; El-Ramly et al. [3, 4] suggested two branches of magmatic differentiation. The first branch would be the result of an original trachy-basalt magma, while the second trend supposedly resulted from the fusion of sialic crust under the influence of the high temperature of the basaltic magma. They confirmed also that the ring complexes of the Egyptian Eastern Desert (Fig. 1) represent the northward continuation of the belt of ring complexes associated with the East African rift system. 


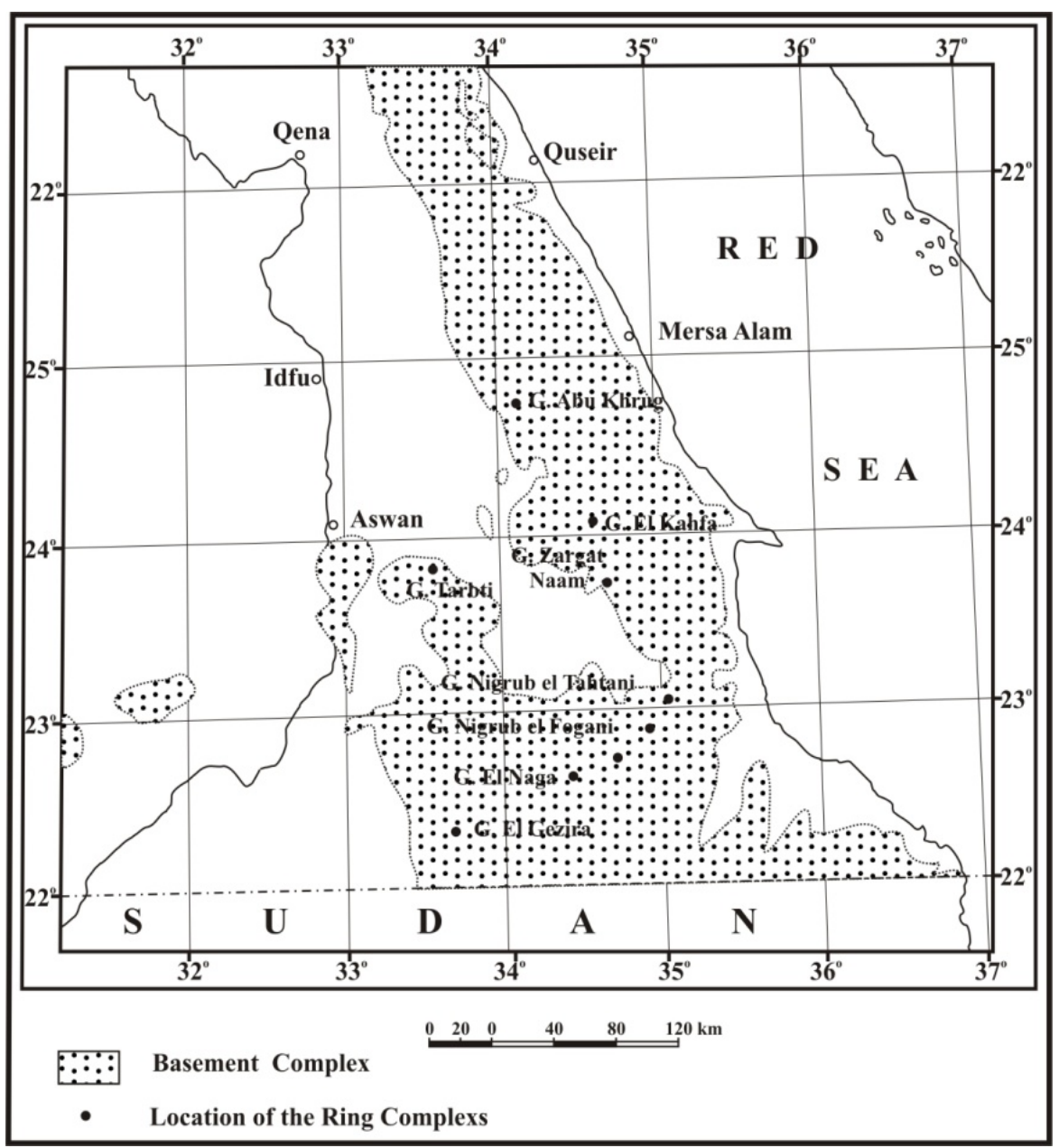

Fig. 1 Key map showing the distribution of the main ring complexes in the South Eastern Desert, Egypt (after El-Ramly [7]).

The distribution of these ring complexes follows either NW or NE trends, where the largest ring complexes are those found as the two trends intersect. Garson and $\mathrm{Krs}$ [8] suggested that the distribution of the ring complexes in Egypt is controlled by $\mathrm{N} 60^{\circ} \mathrm{E}$ crustal block faults and shear zones, and $\mathrm{N} 30^{\circ} \mathrm{W}$ deep-seated tectonic zones related to the opening of the Red Sea.

Serencistes et al. [9] mentioned that the immediate cause of the intrusions of the Egyptian ring complexes may be a heat source in the mantle. This heat may be the same, that cause swelling and updoming in the upper crust, leading to fracturing and rifting. They added that the genesis of the Paleozoic complexes is more likely to be linked to the large-scale faulting pattern of Eastern Africa. These complexes appear to predate any activity connected with the development of the modern Red Sea. They also suggested that the shallow emplacement and short time span of emplacement indicate that the differentiation probably occurred in a magma chamber deep in the crust or upper mantle, rather than in situ.

Hashad and El-Reedy [10] mentioned that the anorogenic alkalic rocks in the South Eastern Desert of Egypt (including El-Kahfa) reflect within-plate tensional environment. Höhndorf et al. [11] on the other hand mentioned that the Egyptian ring complexes have been intruded through the oceanic crust of the Nubian Shield.

Vail [12] referred to three groups of complexes in Egypt based on their ages. The oldest and more saturated massifs $229 \pm 5 \mathrm{Ma}$ (El-Gezira) to $221 \pm 12$ Ma (Silaie), the second and more alkaline ring 
complexes between $148 \pm 12 \mathrm{Ma}$ (Mishbeh) and $132 \pm$ $10 \mathrm{Ma}$ (Mansouri) and the youngest at $95 \pm 5 \mathrm{Ma}$ (El-Kahfa) to $89 \pm 16 \mathrm{Ma}$ (Abu khruq). Vail [12] through his investigation of the ring complexes and related rocks in Africa, concluded that none of these complexes seem to be directly connected with the present African rift systems, although that pattern of faulting is itself related to earlier Precambrian structures. He added that the heterogeneous nature of the ring complex provinces, with the exception of the Cretaceous meridional group, does not support the view of Razvalyayev and Shakhov [13, 14] that the locations of most of the NE Africa and Arabia were controlled by submeridional rift faults associated with east African rift structures.

Abdel Khalek et al. $[15,16]$ concluded that the inner ring syenites in El-Kahfa ring complex is more alkaline and shows a higher differentiation status than those of the outer ring. Their study revealed also that the syenodiorites composition locates between the examined diorites and syenites of the outer ring, where they are formed by the assimilation of the country diorite-masses by the firstly ascending syenite magma.

Ragab et al. [17] concluded that the trace elements contents in El-Kahfa alkali syenites indicate that they were derived from an enriched mantle source in the sub-continental lithosphere, where they originated in an extensional region in a within-plate environment.

From the previous work, it is clear that the origin of El-Kahfa syenites and their geological, geochemical and tectonic implications are not fully understood.

In the present article we present comprehensive petrological and geochemical data, from the different rock unites of El-Kahfa complex in a trial to resolve the controversy on their petrogenesis.

\section{Geologic Setting}

The geologic setting of El-Kahfa ring complex is dictated from the present authors' investigations and El-Ramly et al. [3].

El-Kahfa ring complex comprises an outer ring, an inner ring and a central stock (Figs. 2 and 3a). The ring ridge is not complete and open to the south in the form of a horse shoe ridge. Near its entrance there is a central stock which rises for about $180 \mathrm{~m}$ above the level of the ring wadi.

El-Kahfa country rocks encounter various rock types. The epidiorites surrounded the outer ring. The contact between these epidiorite rocks and the syenites encloses gray rhyodacite xenoliths embedded in generally homogenous syenitic matrix (Fig. 3b).

Metavolcanics are fine-grained, hard and compact basic, intermediate and acidic varieties, exhibiting various colours. They are dissected by some trachytic dykes.

The outer ring is composed of alkaline syenites, which gradually vary from leucocratic syenites barren of quartz to quartz enriched syenites. These rocks are associated and invaded by numerous trachytes.

The inner ring seems to possess a complicated structure and its rocks vary in composition from leucocratic to melanocratic syenite varieties. In equigranular alkaline syenites with quartz and a relatively high percent of dark minerals form its western and northern parts. The inner contacts are covered by wadi alluvium, but highly cataclased and ferruginated rocks are developed at the very foot of its slope.

The central stock is formed essentially of alkali-gabbros. Relics of volcanic cones represented by alkali basalts and their pyroclastic equivalents are preserved in the eastern part of the stock. The alkali-gabbros are cut by small bodies of alkaline syenites, which may occasionally grade into nepheline syenites.

\section{Petrography}

\subsection{Country Rocks}

The country rocks of El-Kahfa ring complex are represented by metavolcanics and epidiorites.

\subsubsection{Metavolcanics}

El-Kahfa metavolcanics are represented mainly by 


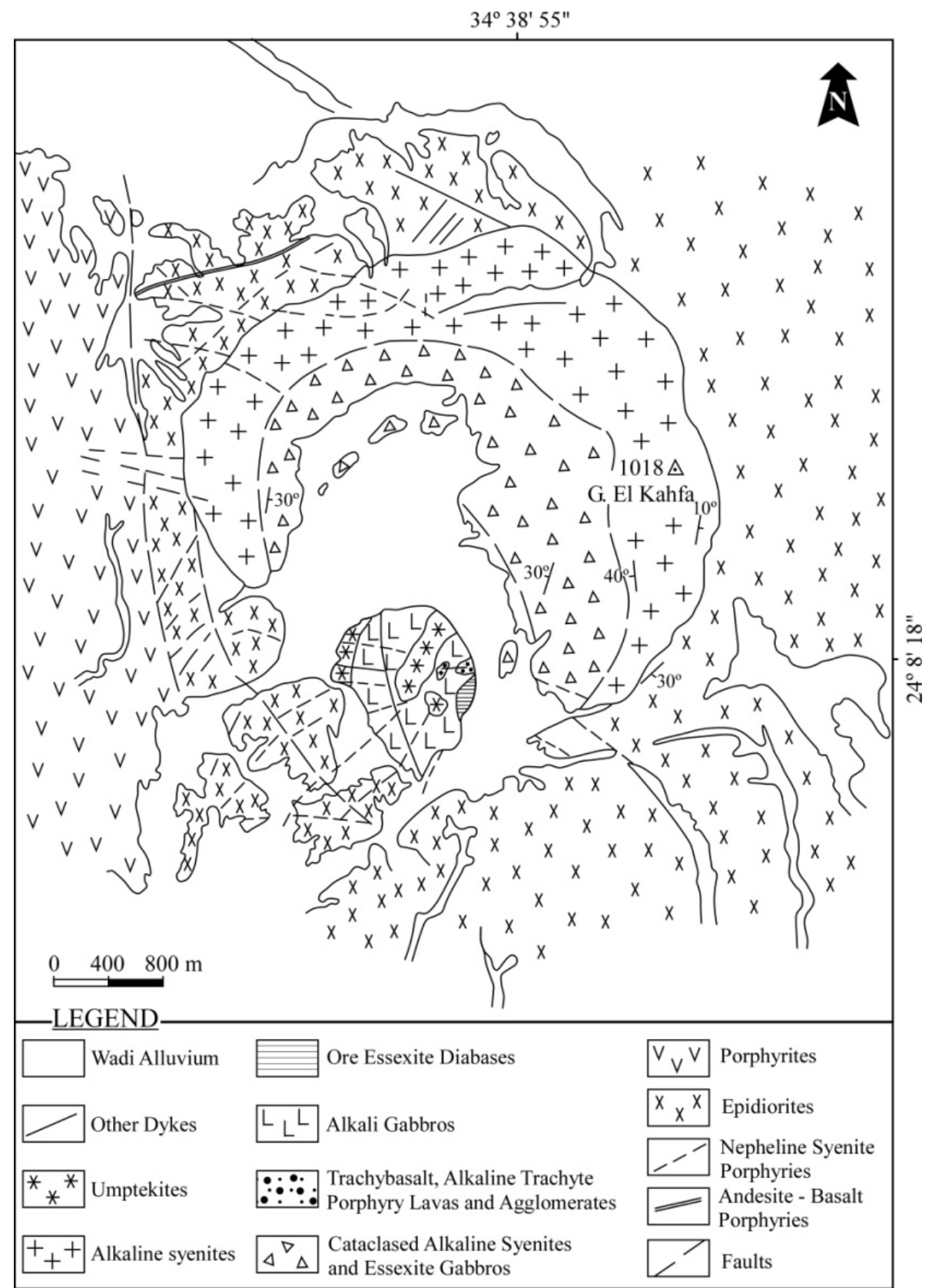

Fig. 2 Geological map of El-Kahfa ring complex, South Eastern Desert, Egypt (modified after El-Ramly et al. [3]).

meta-basalts, meta-andesites and meta-dacites. They are fine grained, exhibiting commonly porphyritic and glomeroporphyritic textures. In the more basic varieties the groundmass varies from microdoloritic to hyalopilitic groundmass.

Plagioclase phenocrysts (mostly andesine $\approx \mathrm{An}_{40}$ ) in the porphyritic varieties are anhedral to subhedral, zoned, cracked and relatively saussuritized. Porphyritic kaolinized K-feldspars can be recorded in the more acidic varieties.

The groundmass is commonly very fine-grained and mostly trachytic (Fig. 4a). The metabasalts groundmass is formed of devitrified glass and spheriolitic feldspar aggregates with doloritic and apodoloritic textures. Amphiboles and biotite predominate among the mafic constituents. In the more basic varieties the groundmass is turbid feldspathic with fine laths of colorless to greenish clinopyroxene, 

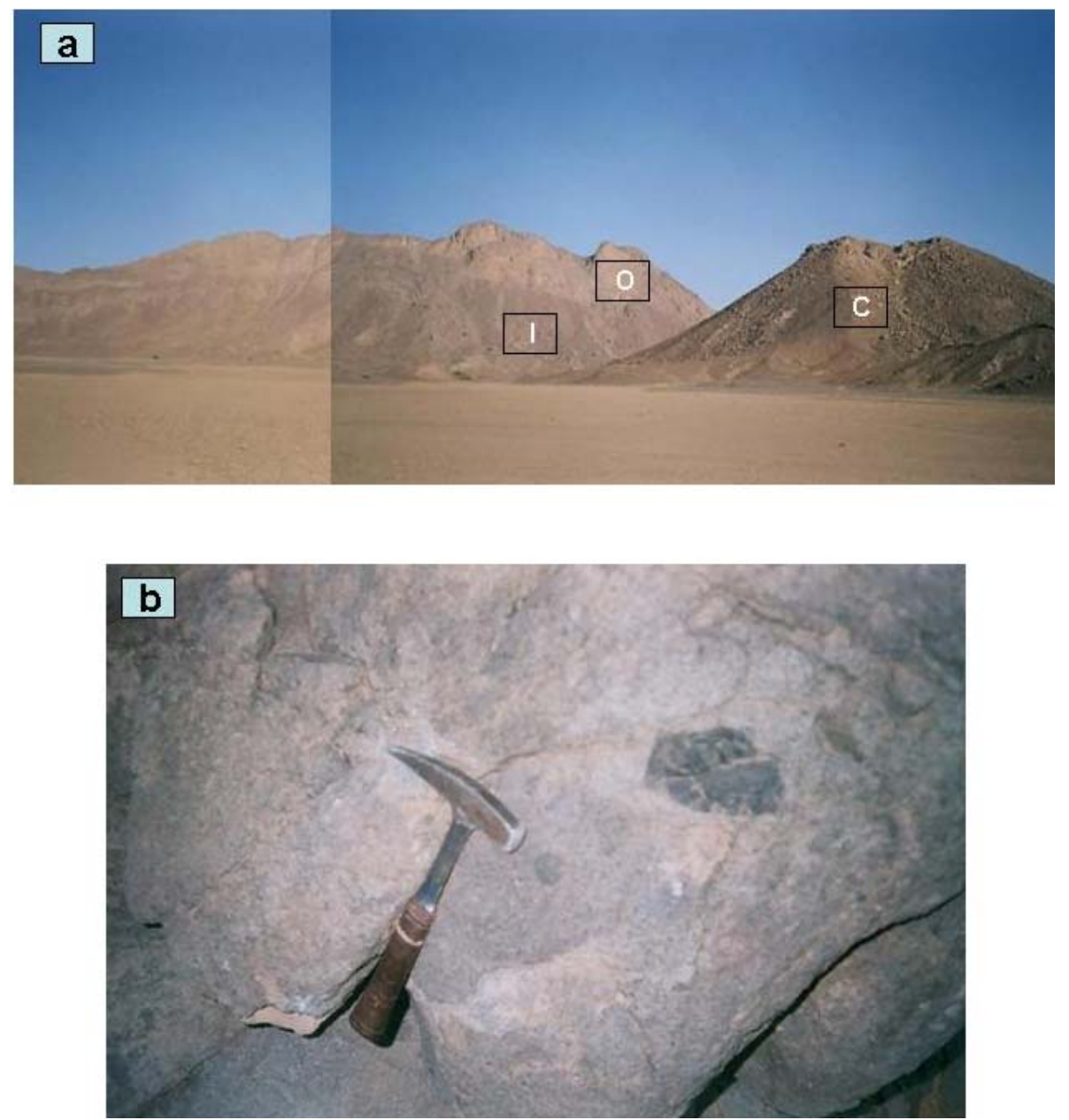

Fig. 3 Photograph of: (a) Panoramic view showing the relation between the inner (I), outer (O) rings and the central stock (C) of El-Kahfa ring complex; (b) Dark gray rhyodacite xenolith embedded in syenitic matrix.

whereas the common amphiboles are greenish hornblende, actinolitic amphibole and occasional kaersutite. In the more acidic varieties the groundmass is mostly quartzo-feldspathic, with fine grains of greenish clinopyroxene, amphiboles and uncommon biotite flakes.

The accessories all over these rocks are opaque Fe-Ti oxides minerals, apatite and sphene.

\subsubsection{Epidiorites}

El-Kahfa epidiorites (meta-gabbros), show hypidiomorphic coarse grained texture. They are constituted mainly of relatively saussuritized zoned andesine plagioclases $\left(\mathrm{An}_{40}\right)$. Mafics are mainly of yellowish-green to green partially epidotized hornblende, that mostly after augitic pyroxene, which occur as relics crowned by that hornblende (Fig. 4b).
Few brown biotite may occur after hornblende. Subhedral clear quartz grows on the expense of the plagioclases and hornblende. Interstitial clear orthoclase grains may compose $5 \%$ to $10 \%$ of the rock constituents. Opaque Fe-Ti oxides minerals grains dispose most of the rock constituents. Zircon and apatite are the common accessories.

\subsection{Ring Complex Rocks}

\subsubsection{Ring Volcanics}

The extrusives associating El-Kahfa ring complex varied from porphyritic trachytes, alkali trachytes to trachy-andesite (latite).

Trachytes are dense (aphanitic) holocrystalline rocks, which are often porphyritic (Fig. 4c). The phenocrysts are mostly of the sanidine alkali-feldspar, whereas 

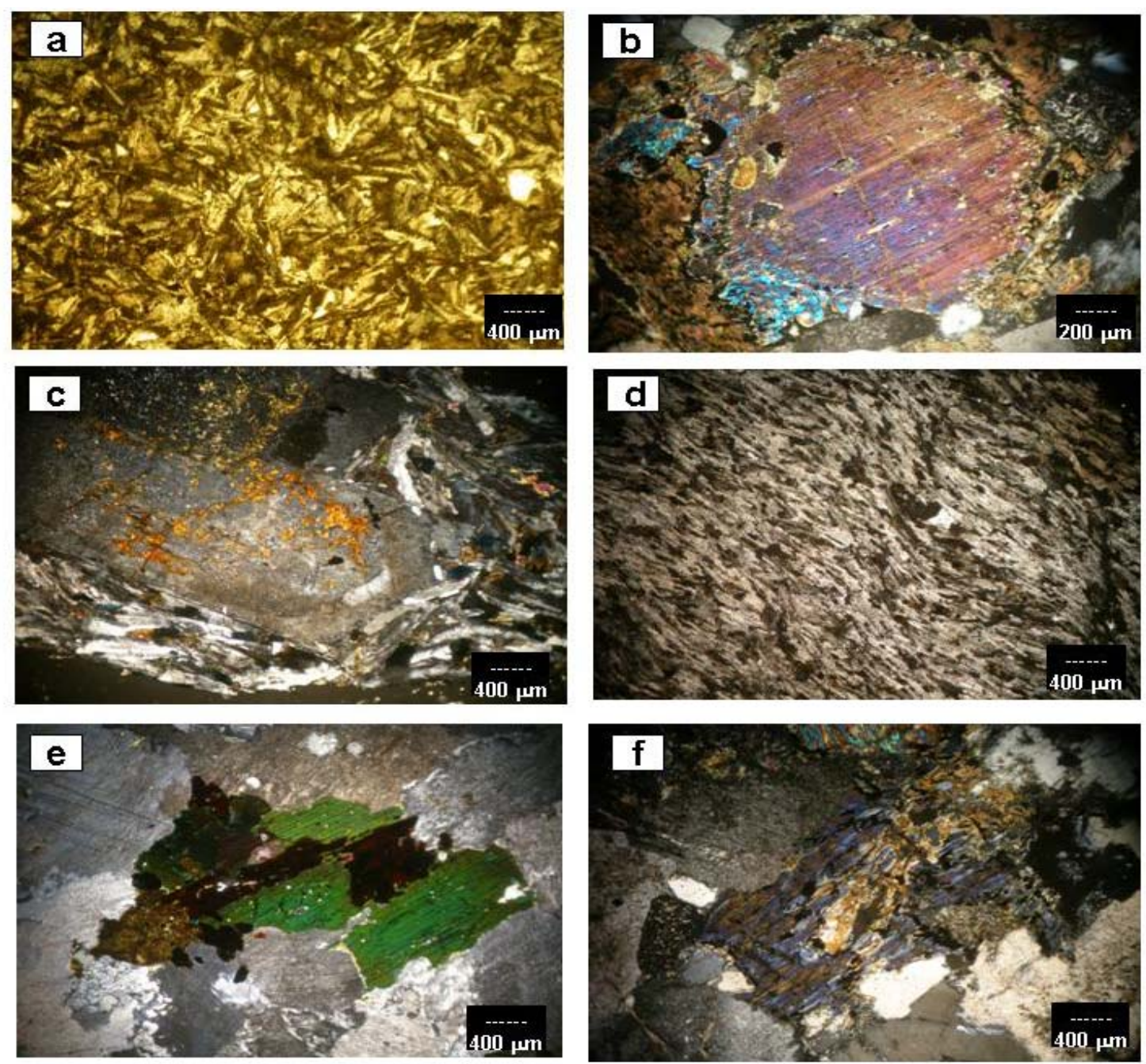

Fig. 4 Photomicrograph of: (a) Metavolcanic showing very fine-grained doleritic groundmass; (b) Epidiorite thin section showing hornblende after pyroxene (sheller texture); (c) Phenocryst of zoned plagioclase in a trachytic groundmass in the porphyritic texture; (d) Trachytic texture in the ring complex trachytes; (e) Aegirine altered to arvedsonite amphibole and aenigmatite surrounded by perthitic feldspars; (f) Syenodiorites showing hornblende altered to chlorite and scarce carbonates.

oligoclase-andesine feldspars present in the more basic trachy-andesites (latite).

The groundmass is dominated by homogenous or cryptoperthitic sanidine and orthoclase, which form slender laths or microlites in parallel orientation exhibiting the trachytic texture, or may form more stout laths giving an orthophyric texture (Fig. 4d).

Aegirine-augite and aegirine, in addition to arfvedsonite and aenigmatite occur in the groundmass as interstitial needles or as fealty aggregates.

Fine interstitial clear quartz grains are uncommon, but cryptocrystalline silica mosaics are noticed in the trachy-andesites. Fine hornblende grains and brown flakes are common in its groundmass, which is disseminated by fine opaque $\mathrm{Fe}$-Ti oxides minerals, whereas accessory apatite grains are also common.

\subsubsection{Syenites}

El-Kahfa syenites vary petrographically from alkali syenites, which form the bulk of the ring syenites, to the alkali quartz bearing syenites and mafic syenites (syenodiorites). These varieties are generally hypidiomorphic granular, coarse to medium grained, whereas pegmatitic and porphyritic varieties can be encountered.

(1) Alkali quartz bearing syenites 
Subhedral microperthitic orthoclase exhibiting micro-string perthitic blebs, represent the main alkali feldspar (modal percent of 85-65\%). Antiperthites are less common. Feldspars are mostly subjected to kaolinization, but relatively free from micro-inclusions. The rarity of these micro-inclusions in the feldspars of these hypersolvus alkaline rocks is indicative of the very low fluid content in the liquid, and under the thermodynamic crystallization conditions of low pressure (less than $2 \mathrm{kbars})$, and high temperature $\left(\approx 500^{\circ} \mathrm{C}\right)$ and less content of F-bearing fluids [18].

Clear subhedral quartz, which represents about $5 \%$ of the rock constituents, is interstitial or forms crystals in microlitic cavities.

Aegerine, with a modal percent range from $10 \%$ to $30 \%$, is strongly pleochroic of deep grass-green to brownish-green. Nevertheless aegirine is relatively fresh, it is generally altered to arfvedsonite, where this alteration may continue the development of riebeckite (Fig. 4e), thus forming the inseparable aegirine-arfvedsonite-rebeckite alteration series. Aenigmatite can also be noticed after aegirine. These Na-pyroboles enclose poiklitically grains of the alkali feldspars and occasionally quartz grains.

Fine-grained apatite is the main accessory, while zircons are also recorded. Subhedral opaque Fe-Ti oxides minerals are in common association with the Na-pyroxenes-Na-amphiboles alteration series.

(2) Alkali syenites

Alkali syenites are generally barren of quartz. Microperthitic to cryptoperthitic, partially kaolinized orthoclase is the main alkali feldspar. These feldspars show string, bleb and occasionally patch perthitization. Antiperthites can be recorded protruding perthites, exhibiting crenulated composition planes.

Secondary fresh, interstitial albite intergrowths grow at the peripheries of the alkali feldspars, which may be formed by the unmixing of the primary high temperature alkali feldspars or by late magmatic albitization [19].

Aegirine with the pleochroic formula $(X=$ deep green, $\mathrm{Y}=$ grass green, $\mathrm{Z}=$ yellowish green), is the main recorded pyroxene, whereas aegirine-augite is not uncommon. Acmite with its brownish to greenish yellow colors, can hardly been noticed especially in the more alkalic varieties.

These alkali pyroxenes are mostly altered to arfvedsonite, which may uncommonly be altered to riebeckitic.

Aenigmatite represents another main alteration product after the aegirine and may acmite.

Kataphorite with the pleochroic formula ( $\mathrm{X}=$ pale brown, $\mathrm{Y}=$ deep brown, $\mathrm{Z}=$ greenish brown), is recorded in the rarely present nepheline-bearing syenites.

Scarce nepheline mostly altered to sodalite can be detected associating the perthitized potash feldspar.

Apatite and opaque Fe-Ti oxides with the less common zircon prevail specially in association with the mafic constituents.

(3) Mafic syenites (syenodiorites)

Mafic syenites or syenodiorites according to Le Maitre [20] are subsolvus syenites intermediate between syenites and diorites. They are constructed of orthoclase, plagioclase, augitic pyroxene, scarce hornblende, biotite and accessories.

Microperthitic orthoclase represents about $45 \%$ of the rock constituents. It is mostly kaolinized. Andesine plagioclase $\left(\mathrm{An}_{30-32}\right)$ is uncommonly zoned with corroded margins. Greenish augitic-pyroxene, with occasional aegirine-augite are the main mafics, which are maybe altered to greenish brown hornblende and yellowish-brown biotite. Chlorite and scarce carbonates represent the main alteration products of these mafics (Fig. 4f).

Scare interstitial secondary clear quartz can be recorded. Epidote and opaque Fe-Ti oxides minerals are the main accessories, in addition to some sphene and zircon.

Generally, El Kahfa syenites lack primary hydrous mafic silicates. This petrographic observation clearly indicates that the syenite magma was anhydrous [21]. 


\subsubsection{Alkali Gabbro}

The nomenclature of this rock variety is after Ref. [22]. In the literature, it was identified as essexite gabbro, which is a miss nomenclature where no nepheline can be noticed in El-Kahfa alkali gabbro, which is essential in essexite gabbro [22]. The rock is medium to coarse grained, hypidiomorphic granular.

Plagioclases $\left(\mathrm{An}_{45-55}\right)$ compose $45-60 \%$ of the rock constituents. They are stumpy, tabular, fractured strained, zoned grains, which are generally saussuritized with occasional carbonitization. Second phase of plagioclase $\left(\mathrm{An}_{50-60}\right)$, more fresh, exhibiting definite lamellar twinning and zoned can be encountered.

Microperthitic orthoclase, which hardly reach up to $20 \%$ of the rock feldspars, are interstitial, partially kaolinized and enclose poiklitically plagioclases.

Mafics representing $\approx 40 \%$ of the rock constituents are represented mostly by Ca-rich augite (salite), which shows pale-green to violet tinted varieties. Aegirine-augite can occasionally be noticed on the peripheries of the Ca-rich augites. This is in accordance with what mentioned by Ref. [22] that the initial stage of $\mathrm{Na}-\mathrm{Fe}^{3+}$ enrichment is represented by violet tinted or pale green soda augites $\left(\mathrm{Na}_{2} \mathrm{O}>1.5 \%\right.$; [23-25]) either rimming more diopsidic cores or forming discrete crystals which may be rimmed by aegirine-augite or aegirine.

These pyroxenes are uncommonly mantled by uralitic green amphibole, with bluish tint, and partially disposed with opaques. This amphibole is associated with a yellowish cryptocrystalline to microcrystalline undefined. Bonin [18] noticed that the calcic and ferric clinopyroxenes are frequently altered to cryptocrystalline substance that shows a clear green-yellow pleochroism, which is always enclosed in green calcic amphibole. Bonin [18] added that in the wake of the work of the subcommision on Amphibole of the IMA (Leake, 1978), the optical variation within the amphiboles is revealed to be so complicated and so little linked to compositional changes.
Madhaven et al. [21] referred that hedenbergite pyroxene frequently alters (Topotaxial alteration) to an orange-yellow coloured montronite, which is formed by the oxidation of $\mathrm{Fe}^{2+}$ to $\mathrm{Fe}^{3+}$ with the simultaneous release of $\mathrm{Ca}$ as observed by Eggleton [26] in the Australian skarns:

$$
\mathrm{Ca}_{2} \mathrm{Fe}_{2}^{+2} \mathrm{Si}_{4} \mathrm{O}_{12}+2 \mathrm{H} \rightarrow \mathrm{Fe}^{+3} \mathrm{Si}_{4} \mathrm{O}_{10}(\mathrm{OH})^{2+}+2 \mathrm{Ca}
$$

Barkevikite, with the pleochroic formula $(\mathrm{X}=$ yellow, $\mathrm{Y}=$ yellowish-brown and $\mathrm{Z}=$ brown), is recorded as subhedral to anhedral grains, which are disseminated with opaques.

Medium to coarse grained apatite is a ubiquitous accessory mineral. It is mostly intermixed with the pyroxenes alteration products.

\section{Geochemistry}

Total seventeen representative samples from El-Kahfa ring complex and its country rocks were analyzed for major elements (Table 1) at NMA (Nuclear Materials Authority) laboratories, using conventional wet chemical techniques of Shapiro and Brannock [27] with some modifications given by El-Reedy [28]. Ten representative samples of the syenites and associated trachytes were investigated for their trace elements and REE at ACME analytical laboratories, Vancouver, Canada, using the ICP-Ms techniques (Table 2).

\subsection{Major and Trace Elements}

The distribution of the major oxides and the trace elements of El-Kahfa ring complex (Tables 1 and 2) indicates that El-Kahfa rocks are represented by undersaturated alkaline varieties. It can steadily report that, the silica content in El-Kahfa complex exhibit a distinct gap separating the undersaturated alkali-basalts (47.88\%) and alkali gabbros (49.16\%) from the alkali trachytes (57.91\%) and alkali syenites (64.44\%).

Bryan [29] and Wilkinson [25] have pointed out that silica-gaps are characteristic of differentiated intrusions, which provide some of the best evidence for fractional crystallization. 
Table 1 Chemical analyses of major oxides (wt.\%) and computerized CIPW-normative minerals for El-Kahfa ring complexes samples.

\begin{tabular}{|c|c|c|c|c|c|c|c|c|}
\hline Rock type & Alk. Basalt & Alk. Gabbro & Epidiorite & & & Trachytes & & \\
\hline S. No. & K14 & K11 & K1 & K10 & K13a & $\mathrm{K} 13 \mathrm{~b}$ & $\mathrm{~K} 3$ & $\mathrm{~K} 7$ \\
\hline $\mathrm{SiO}_{2}$ & 47.88 & 49.16 & 60.63 & 66.22 & 69.41 & 63.18 & 61.26 & 57.91 \\
\hline $\mathrm{TiO}_{2}$ & 1.32 & 2.22 & 0.96 & 0.40 & 0.51 & 0.24 & 0.36 & 0.73 \\
\hline $\mathrm{Al}_{2} \mathrm{O}_{3}$ & 15.34 & 17.43 & 15.52 & 12.96 & 19.56 & 15.40 & 19.07 & 18.59 \\
\hline $\mathrm{Fe}_{2} \mathrm{O}_{3}$ & 1.82 & 7.26 & 1.92 & 1.50 & 0.73 & 2.58 & 2.96 & 3.04 \\
\hline $\mathrm{FeO}$ & 8.02 & 7.19 & 4.71 & 2.30 & 1.63 & 2.81 & 3.12 & 4.25 \\
\hline $\mathrm{FeO}^{*}$ & 11.46 & 13.72 & 6.44 & 3.65 & 2.29 & 5.13 & 5.78 & 6.99 \\
\hline $\mathrm{Fe}_{2} \mathrm{O}_{3} *$ & 12.73 & 15.25 & 7.15 & 4.06 & 2.54 & 5.70 & 6.43 & 7.76 \\
\hline $\mathrm{MnO}$ & 0.12 & 0.16 & 0.12 & 0.06 & 0.10 & 0.09 & 0.15 & 0.12 \\
\hline $\mathrm{MgO}$ & 4.01 & 2.82 & 3.02 & 0.32 & 0.32 & 1.02 & 1.60 & 0.40 \\
\hline $\mathrm{CaO}$ & 14.00 & 9.23 & 7.89 & 1.56 & 1.56 & 2.80 & 2.68 & 2.57 \\
\hline $\mathrm{Na}_{2} \mathrm{O}$ & 2.97 & 2.02 & 2.15 & 7.65 & 2.46 & 6.52 & 4.03 & 4.97 \\
\hline $\mathrm{K}_{2} \mathrm{O}$ & 0.31 & 1.15 & 0.63 & 2.41 & 1.19 & 3.18 & 2.02 & 3.79 \\
\hline $\mathrm{P}_{2} \mathrm{O}_{5}$ & 0.24 & 0.37 & 0.21 & 0.04 & 0.60 & 0.04 & 0.20 & 0.50 \\
\hline L.O.I & 0.16 & 0.61 & 0.30 & 1.11 & 0.48 & 0.46 & 0.84 & 1.03 \\
\hline Total & 96.19 & 99.62 & 98.14 & 96.52 & 98.55 & 97.86 & 98.29 & 97.90 \\
\hline \multicolumn{9}{|c|}{ CIPW-normative values } \\
\hline $\mathrm{Mg} \#$ & 47.13 & 41.15 & 13.15 & 19.88 & 25.93 & 39.29 & 47.76 & 14.37 \\
\hline Q & 0.00 & 10.16 & 24.33 & 43.41 & 48.41 & 6.84 & 21.69 & 7.99 \\
\hline $\mathrm{C}$ & 0.00 & 0.00 & 0.00 & 0.00 & 12.92 & 0.00 & 5.95 & 2.78 \\
\hline Or & 1.87 & 0.87 & 3.81 & 14.67 & 7.18 & 19.22 & 12.26 & 23.14 \\
\hline $\mathrm{Ab}$ & 23.88 & 17.24 & 18.59 & 0.00 & 21.20 & 56.30 & 34.95 & 43.36 \\
\hline An & 28.12 & 35.39 & 31.50 & 0.00 & 4.30 & 3.41 & 12.45 & 10.14 \\
\hline $\mathrm{Ne}$ & 0.93 & 0.00 & 0.00 & 0.00 & 0.00 & 0.00 & 0.00 & 0.00 \\
\hline $\mathrm{Lc}$ & 0.00 & 0.00 & 0.00 & 0.00 & 0.00 & 0.00 & 0.00 & 0.00 \\
\hline Ac & 0.00 & 0.00 & 0.00 & 4.46 & 0.00 & 0.00 & 0.00 & 0.00 \\
\hline Ns & 0.00 & 0.00 & 0.00 & 14.32 & 0.00 & 0.00 & 0.00 & 0.00 \\
\hline Di & 34.11 & 7.12 & 5.98 & 11.54 & 0.00 & 8.75 & 0.00 & 0.00 \\
\hline Wo & 17.24 & 3.67 & 3.05 & 5.71 & 0.00 & 4.40 & 0.00 & 0.00 \\
\hline En & 8.59 & 2.24 & 1.67 & 2.06 & 0.00 & 2.09 & 0.00 & 0.00 \\
\hline Fs & 8.27 & 1.21 & 1.26 & 3.78 & 0.00 & 2.25 & 0.00 & 0.00 \\
\hline Нy & 0.00 & 7.51 & 10.61 & 0.00 & 2.58 & 1.07 & 7.15 & 5.47 \\
\hline HyEn & 0.00 & 4.88 & 6.05 & 0.00 & 0.82 & 0.51 & 4.10 & 1.03 \\
\hline HyFs & 0.00 & 2.63 & 4.56 & 0.00 & 1.76 & 0.55 & 3.04 & 4.44 \\
\hline $\mathrm{Ol}$ & 2.35 & 0.00 & 0.00 & 0.00 & 0.00 & 0.00 & 0.00 & 0.00 \\
\hline OlFo & 1.14 & 0.00 & 0.00 & 0.00 & 0.00 & 0.00 & 0.00 & 0.00 \\
\hline $\mathrm{OlFa}$ & 1.21 & 0.00 & 0.00 & 0.00 & 0.00 & 0.00 & 0.00 & 0.00 \\
\hline Mt & 5.65 & 10.63 & 2.85 & 0.00 & 1.08 & 3.79 & 4.40 & 4.55 \\
\hline $\mathrm{Hm}$ & 0.00 & 0.00 & 0.00 & 0.00 & 0.00 & 0.00 & 0.00 & 0.00 \\
\hline Il & 2.56 & 4.26 & 1.87 & 0.78 & 0.99 & 0.54 & 0.70 & 1.43 \\
\hline Ap & 0.53 & 0.82 & 0.47 & 0.09 & 1.34 & 0.09 & 0.45 & 1.13 \\
\hline
\end{tabular}


(Table 1 to be continued)

\begin{tabular}{|c|c|c|c|c|c|c|c|c|c|}
\hline \multicolumn{3}{|c|}{ Rock type } & \multicolumn{3}{|c|}{ Syenite } & \multicolumn{2}{|c|}{ Syenodiorites } & \multicolumn{2}{|c|}{ Alkaline syenite } \\
\hline S. No. & K15 & K30 & K30a & $\mathrm{K} 5$ & K9 & K1a & K25 & K26 & K32 \\
\hline $\mathrm{SiO}_{2}$ & 63.81 & 60.68 & 61.35 & 60.20 & 60.80 & 62.05 & 59.76 & 65.46 & 64.44 \\
\hline $\mathrm{TiO}_{2}$ & 0.41 & 0.80 & 0.48 & 0.44 & 0.40 & 0.31 & 0.80 & 0.02 & 0.19 \\
\hline $\mathrm{Al}_{2} \mathrm{O}_{3}$ & 14.51 & 16.40 & 15.00 & 11.31 & 16.80 & 16.32 & 17.05 & 17.92 & 16.98 \\
\hline $\mathrm{Fe}_{2} \mathrm{O}_{3}$ & 3.02 & 4.08 & 3.88 & 3.72 & 4.82 & 1.16 & 3.08 & 0.73 & 1.65 \\
\hline $\mathrm{FeO}$ & 2.06 & 2.52 & 3.40 & 3.62 & 3.81 & 4.59 & 3.51 & 1.61 & 3.19 \\
\hline $\mathrm{FeO}^{*}$ & 4.78 & 6.10 & 6.89 & 6.97 & 8.15 & 5.63 & 6.28 & 2.27 & 4.67 \\
\hline $\mathrm{Fe}_{2} \mathrm{O}_{3} *$ & 5.31 & 6.88 & 7.66 & 7.74 & 9.05 & 6.26 & 6.98 & 2.52 & 5.19 \\
\hline $\mathrm{MnO}$ & 0.15 & 0.13 & 0.12 & 0.11 & 0.15 & 0.23 & 0.08 & 0.08 & 0.05 \\
\hline $\mathrm{MgO}$ & 1.10 & 1.90 & 2.02 & 3.02 & 0.83 & 6.07 & 3.18 & 1.20 & 1.40 \\
\hline $\mathrm{CaO}$ & 2.80 & 2.80 & 2.80 & 4.20 & 2.24 & 3.36 & 6.56 & 2.84 & 2.40 \\
\hline $\mathrm{Na}_{2} \mathrm{O}$ & 7.20 & 7.20 & 7.20 & 6.97 & 6.74 & 3.65 & 2.04 & 1.46 & 2.31 \\
\hline $\mathrm{K}_{2} \mathrm{O}$ & 3.35 & 1.86 & 2.41 & 4.69 & 3.10 & 1.33 & 0.84 & 1.26 & 2.06 \\
\hline $\mathrm{P}_{2} \mathrm{O}_{5}$ & 0.03 & 0.18 & 0.23 & 0.10 & 0.08 & 0.20 & 0.60 & 0.05 & 0.18 \\
\hline L.O.I & 0.15 & 0.09 & 0.09 & 0.42 & 0.12 & 0.64 & 0.39 & 0.84 & 0.12 \\
\hline Total & 98.59 & 98.64 & 98.98 & 98.80 & 99.77 & 96.23 & 97.89 & 93.47 & 94.97 \\
\hline \multicolumn{10}{|c|}{ CIPW-normative values } \\
\hline $\mathrm{Mg} \#$ & 48.77 & 57.34 & 51.44 & 59.8 & 28.46 & 70.22 & 61.76 & 57.06 & 43.90 \\
\hline Q & 35.02 & 4.62 & 3.17 & 19.95 & 3.65 & 16.74 & 26.82 & 46.72 & 36.28 \\
\hline $\mathrm{C}$ & 0.00 & 0.00 & 0.00 & 0.00 & 0.00 & 3.21 & 2.18 & 9.81 & 7.34 \\
\hline Or & 20.13 & 11.16 & 14.41 & 28.20 & 18.17 & 7.92 & 5.10 & 8.05 & 12.85 \\
\hline $\mathrm{Ab}$ & 0.00 & 61.75 & 61.53 & 0.00 & 57.08 & 31.08 & 17.68 & 13.32 & 20.58 \\
\hline An & 0.00 & 7.02 & 1.49 & 0.00 & 6.41 & 15.62 & 29.79 & 14.90 & 11.45 \\
\hline $\mathrm{Ne}$ & 0.00 & 0.00 & 0.00 & 0.00 & 0.00 & 0.00 & 0.00 & 0.00 & 0.00 \\
\hline $\mathrm{Lc}$ & 0.00 & 0.00 & 0.00 & 0.00 & 0.00 & 0.00 & 0.00 & 0.00 & 0.00 \\
\hline $\mathrm{Ac}$ & 8.86 & 0.00 & 0.00 & 10.92 & 0.00 & 0.00 & 0.00 & 0.00 & 0.00 \\
\hline Ns & 12.05 & 0.00 & 0.00 & 11.06 & 0.00 & 0.00 & 0.00 & 0.00 & 0.00 \\
\hline Di & 11.60 & 4.69 & 9.05 & 16.90 & 3.55 & 0.00 & 0.00 & 0.00 & 0.00 \\
\hline Wo & 5.82 & 2.51 & 4.67 & 8.59 & 1.78 & 0.00 & 0.00 & 0.00 & 0.00 \\
\hline En & 2.60 & 2.11 & 2.94 & 4.59 & 0.79 & 0.00 & 0.00 & 0.00 & 0.00 \\
\hline Fs & 3.19 & 0.08 & 1.44 & 3.72 & 0.98 & 22.71 & 0.00 & 0.00 & 0.00 \\
\hline Hy & 0.44 & 2.81 & 3.22 & 5.58 & 2.99 & 15.29 & 10.95 & 2.90 & 8.19 \\
\hline HyEn & 0.20 & 2.71 & 2.16 & 3.08 & 1.34 & 7.43 & 8.15 & 3.24 & 3.69 \\
\hline HyFs & 0.24 & 0.10 & 1.06 & 2.50 & 1.65 & 0.00 & 2.79 & 2.66 & 4.50 \\
\hline $\mathrm{Ol}$ & 0.00 & 0.00 & 0.00 & 0.00 & 0.00 & 0.00 & 0.00 & 0.00 & 0.00 \\
\hline OlFo & 0.00 & 0.00 & 0.00 & 0.00 & 0.00 & 0.00 & 0.00 & 0.00 & 0.00 \\
\hline $\mathrm{OlFa}$ & 0.00 & 0.00 & 0.00 & 0.00 & 0.00 & 1.69 & 0.00 & 0.00 & 0.00 \\
\hline $\mathrm{Mt}$ & 0.00 & 6.00 & 5.69 & 0.00 & 7.00 & 1.69 & 4.58 & 1.14 & 2.52 \\
\hline $\mathrm{Hm}$ & 0.00 & 0.00 & 0.00 & 0.00 & 0.00 & 0.00 & 0.00 & 0.00 & 0.00 \\
\hline Il & 0.79 & 1.54 & 0.92 & 0.85 & 0.76 & 0.59 & 1.56 & 0.04 & 0.38 \\
\hline Ap & 0.07 & 0.40 & 0.51 & 0.22 & 0.18 & 0.44 & 1.34 & 0.12 & 0.41 \\
\hline
\end{tabular}

Le Maitre [30] referred that the paucity of intermediate lavas in basalt-trachyte sequences may be due to a discrimination in the eruptive process, and not to the scarcity of intermediate magma, i.e. which trachy-andesitic magma formed at depth has not been erupted at the surface as readily as more basic and more salic magma.

MacDonald [31] mentioned that these gaps may reflect the following:

(1) Some sort of physical control in which rise to the surface is prevented by high viscosity and/or density $[32,33]$. 
Table 2 Trace elements (ppm) and some elemental ratios of El-Kahfa rocks.

\begin{tabular}{|c|c|c|c|c|c|c|c|c|c|c|}
\hline Rock type & Epidio. & Alk. Gab. & & Trachy & & & Syeni & & Sye & diorite \\
\hline S. No. & K1 & K11 & $\mathrm{K} 13 \mathrm{a}$ & K7 & K3 & $\begin{array}{l}\text { k26a } \\
\text { Alk. }\end{array}$ & $\begin{array}{l}\text { K32a } \\
\text { Alk. }\end{array}$ & K9 & K1a & K25 \\
\hline $\mathrm{Ba}$ & 240.00 & 52.00 & 342.00 & 153.00 & 4.26 & 155.0 & 228.00 & 466.00 & 91.00 & 115.00 \\
\hline $\mathrm{Rb}$ & 32.80 & 4.60 & 59.20 & 179.00 & 111.60 & 133.10 & 47.80 & 82.70 & 15.70 & 73.50 \\
\hline $\mathrm{Sr}$ & 401.60 & 209.70 & 36.60 & 46.50 & 20.60 & 15.10 & 37.10 & 25.20 & 26.10 & 417.08 \\
\hline $\mathrm{Y}$ & 25.40 & 25.60 & 66.90 & 123.80 & 128.70 & 55.30 & 14.50 & 44.70 & 74.20 & 44.90 \\
\hline $\mathrm{Zr}$ & 195.30 & 48.10 & $1,144.4$ & $2,128.7$ & $1,342.40$ & $1,543.60$ & 230.80 & 597.00 & 868.00 & 712.00 \\
\hline $\mathrm{Nb}$ & 6.60 & 2.40 & 213.40 & $383 . .3$ & 37.10 & 170.70 & 26.60 & 120.00 & 174.20 & 134.70 \\
\hline Th & 3.80 & 0.30 & 22.60 & 42.90 & 30.50 & 16.40 & 3.40 & 11.80 & 16.30 & 12.80 \\
\hline $\mathrm{Pb}$ & 3.10 & 0.80 & 11.60 & 22.30 & 6.40 & 4.30 & 2.00 & 4.90 & 4.70 & 2.40 \\
\hline $\mathrm{Ga}$ & 18.30 & 17.90 & 31.9 & 41.90 & 37.40 & 45.50 & 47.40 & 32.30 & 38.20 & 28.70 \\
\hline $\mathrm{Zn}$ & 56.00 & 47.00 & 24.00 & 105.00 & 48.00 & 13.00 & 28.00 & 21.00 & 28.00 & 64.00 \\
\hline $\mathrm{Cu}$ & 51.10 & 28.00 & 7.10 & 2.20 & 0.80 & 1.60 & 1.20 & 2.20 & 11.20 & 9.90 \\
\hline $\mathrm{Ni}$ & 24.30 & 5.00 & 1.50 & 1.90 & 0.80 & 14.00 & 1.300 & 0.70 & 3.40 & 0.80 \\
\hline V & 156.00 & 404.00 & 19.00 & 8.00 & 7.50 & 6.00 & 6.00 & 7.00 & 17.00 & 7.00 \\
\hline Hf & 5.60 & 1.60 & 27.30 & 47.70 & 34.00 & 33.30 & 6.60 & 14.20 & 21.40 & 16.30 \\
\hline Cs & 0.80 & 0.20 & 0.20 & 0.50 & 1.00 & 0.50 & 0.20 & 0.40 & 0.10 & 5.30 \\
\hline $\mathrm{Ta}$ & 1.30 & 13.00 & 15.69 & 21.10 & 19.40 & 14.50 & 4.10 & 10.60 & 10.50 & 9.01 \\
\hline Co & 19.70 & 32.50 & 0.60 & 1.70 & 0.40 & 0.90 & 11.00 & 2.20 & 1.30 & 4.70 \\
\hline $\mathrm{Be}$ & 1.00 & 0.80 & 4.00 & 11.00 & 8.00 & 8.00 & 4.00 & 4.00 & 5.00 & 4.00 \\
\hline $\mathrm{U}$ & 3.80 & 0.90 & 8.00 & 10.90 & 9.50 & 7.60 & 3.60 & 5.00 & 5.40 & 7.00 \\
\hline W & 3.20 & 1.20 & 6.80 & 2.30 & 3.70 & 4.70 & 2.20 & 3.30 & 4.00 & 3.00 \\
\hline Sn & 2.00 & 0.70 & 8.00 & 17.00 & 15.00 & 8.00 & 3.00 & 4.00 & 7.00 & 5.00 \\
\hline Mo & 0.60 & 0.20 & 3.70 & 1.20 & 0.80 & 1.20 & 1.30 & 2.50 & 1.10 & 4.30 \\
\hline $\mathrm{Au}$ & 0.30 & 0.30 & 0.80 & 3.00 & 0.60 & 3.0 & 0.80 & n.d. & 3.70 & n.d. \\
\hline $\mathrm{Th} / \mathrm{U}$ & 1 & 0.33 & 2.83 & 3.94 & 3.21 & 2.16 & 0.95 & 2.36 & 3.02 & 1.83 \\
\hline $\mathrm{Zr} / \mathrm{Nb}$ & 29.60 & 20.04 & 5.36 & 5.55 & 36.18 & 9.04 & 8.68 & 4.98 & 4.98 & 5.29 \\
\hline $\mathrm{Sr} / \mathrm{Rb}$ & 12.24 & 45.59 & 0.62 & 0.26 & 0.18 & 0.11 & 0.78 & 0.30 & 1.66 & 5.67 \\
\hline
\end{tabular}

n.d.: not detected.

(2) A control is related to the crystallization process itself, where the intermediate composition range is seen as one of rapid crystallization over a narrow temperature interval producing low volumes of melt [34]. The appropriate compositions are then found - perhaps exclusively - as margins to the major crystallizing phases within the magma chamber. Weaver [34] added that one untested possibility is that the onset of crystallization of Fe-Ti oxides produces rapid changes in major element composition, especially $\mathrm{SiO}_{2}$.

Weaver [34] and Clague [35] related also the $\mathrm{SiO}_{2}$ jump to Fe-Ti oxidation proportion. The position of the composition gap in a magmatic series would then be critically dependant on the point at which oxides began to precipitate, which is perhaps a function of $\mathrm{pO} 2$.

(3) A real absence of intermediate materials, plus the relatively high ratio of salic-to-mafic products, have encouraged the idea that the basalts and trachytes have different sources.

Gasparon et al. [36] concluded that crustal anatexis nicely explains the large volumes of acid rocks and the scarcity or absence of basaltic counterparts.

Bishady [37] through his investigation of the two ring complexes El-Gezira and Mansouri, proposed that the more salic varieties were derived from the alkali-basalts by fractional crystallization, but with minor continental crust contamination as Norry et al. [38] preferred for Kenya lavas.

The plots of the trachytes and syenites on the TAS 
(total alkalis-silica) diagram of Le Maitre [20] (Fig. 5a) are mostly fall in the fields of syenites (trachytes), syenodiorites (trachyandesites), whereas some of them locate around the granodiorite (dacite) fields. The epidiorites are close to the syenodiorite samples, while the alkali-gabbro and alkali basalts are in the field of gabbro (basalt). In terms of the normative mineralogy, the syenites and trachytes occupy the different fields of granites on the QAP diagram of Strekeisen [39] (Fig. $5 b)$, from the quartz-rich granitoids, through alkali-feldspar granites to the field of alkali-syenites. Epidiorites and syenodiorites plot in the field of monzogranites, whereas alkali-gabbros plot in the field of quartz-monzonites, and the alkali-basalts in the field of monzonite.

Harker type diagrams (Fig. 6) show that there is an overall decrease in $\mathrm{MgO}, \mathrm{CaO}, \mathrm{FeO}^{\mathrm{t}}$ and $\mathrm{TiO}_{2}$. These oxides essentially enter the composition of the coloured minerals, which are abundant in the mesocratic undersaturated rocks, rather than the leucocratic saturated varieties. This can reflect the crystallization of early plagioclase followed by $\mathrm{Fe}-\mathrm{Ti}$ oxides minerals and finally alkali feldspars.

Bonin and Lameyre [40] and Bonin [18] explained the abrupt fall in $\mathrm{MgO}$ (nearly zero) and $\mathrm{Fe}_{2} \mathrm{O}$ with points of inflection at about $60 \%$ silica content, that is essentially due to the ferriferous nature of the mafic minerals in syenites.

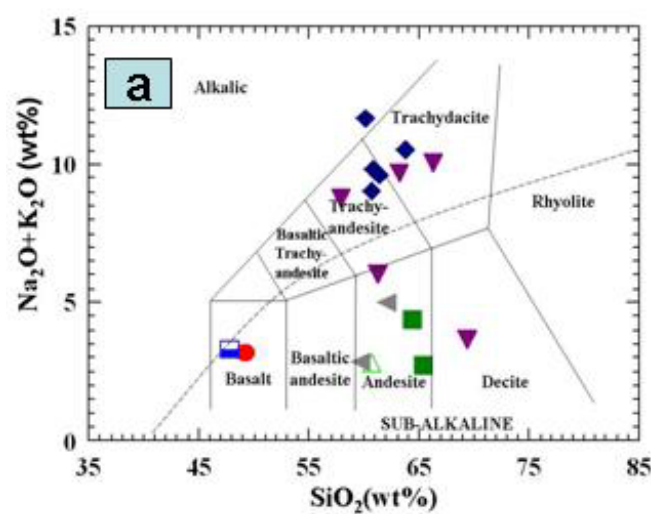

Alkali Gabbro $\triangle$ Epidiorite Syenite

Syenodiorite
The variably high $\mathrm{MgO}, \mathrm{FeO}^{\mathrm{t}}$ and $\mathrm{Ni}$ in alkali-gabbros and alkali-basalts (Tables 1 and 2) are consistent with their derivation evolved from mantle melts [21].

A weak trend of the iron enrichment in the early stage of differentiation is clear on the AFM diagram, (Fig. 7a). This could be designed as that these rocks are of the alkali-basalt series [41].

The alkaline nature of the syenites and trachytes is noticed on the variation diagram $\mathrm{SiO}_{2}$ versus total alkalis of Irvine and Baragar [42] (Fig. 7b). The alkali-gabbro and alkali-basalt plot in the subalkaline field close to the alkaline field border, which can be due to their low $\mathrm{SiO}_{2}$, low $\mathrm{K}_{2} \mathrm{O}$ and very low $\mathrm{K}_{2} \mathrm{O} / \mathrm{Na}_{2} \mathrm{O}$ (Table 1).

Based on the ratios $(\mathrm{A} / \mathrm{CNK})$ and $(\mathrm{A} / \mathrm{NK})$ $\left[\mathrm{Al}_{2} \mathrm{O}_{3} /\left(\mathrm{CaO}+\mathrm{Na}_{2} \mathrm{O}+\mathrm{K}_{2} \mathrm{O}\right)\right.$ and $\left.\mathrm{Al}_{2} \mathrm{O}_{3} /\left(\mathrm{Na}_{2} \mathrm{O}+\mathrm{K}_{2} \mathrm{O}\right)\right]$ (Table 1), most of the trachytes and syenite samples are peraluminous (A/CNK varies from 1.81 to 2.81), except one syenite sample are peralkaline $(\mathrm{A} / \mathrm{CNK}=$ $0.71)$. The epidiorites are also peraluminous, while the alkali basalts is metaluminous $(\mathrm{A} / \mathrm{CNK}=0.89)$.

MacDonald [43] suggested that the degree of peralkalinity achieved by a given magma series will depend, not only on the initial composition of the basaltic parents, but also on the magma crystallization history. For example fractionation from basaltic melts of unusually large amount of calcic-plagioclase relative

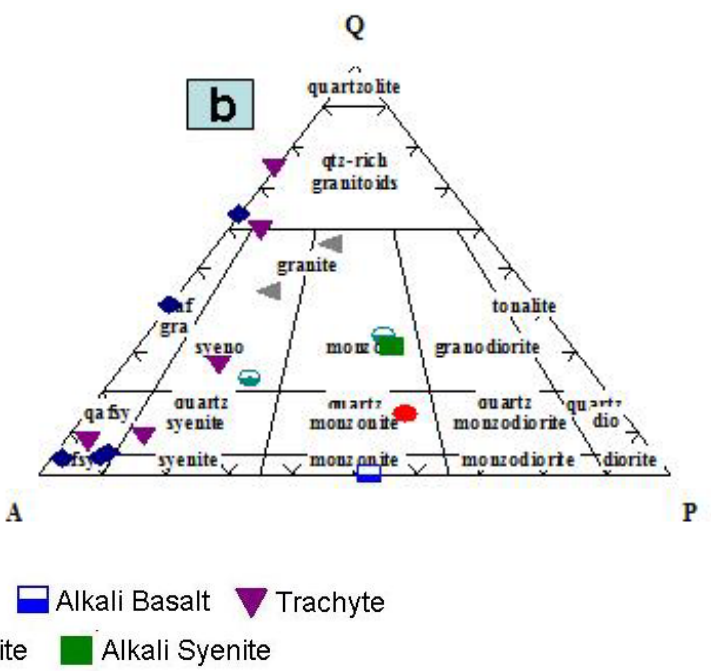

Fig. 5 (a) TAS diagram of Le Maitre [20]; (b) QAP diagram of Strekeisen [39]. 

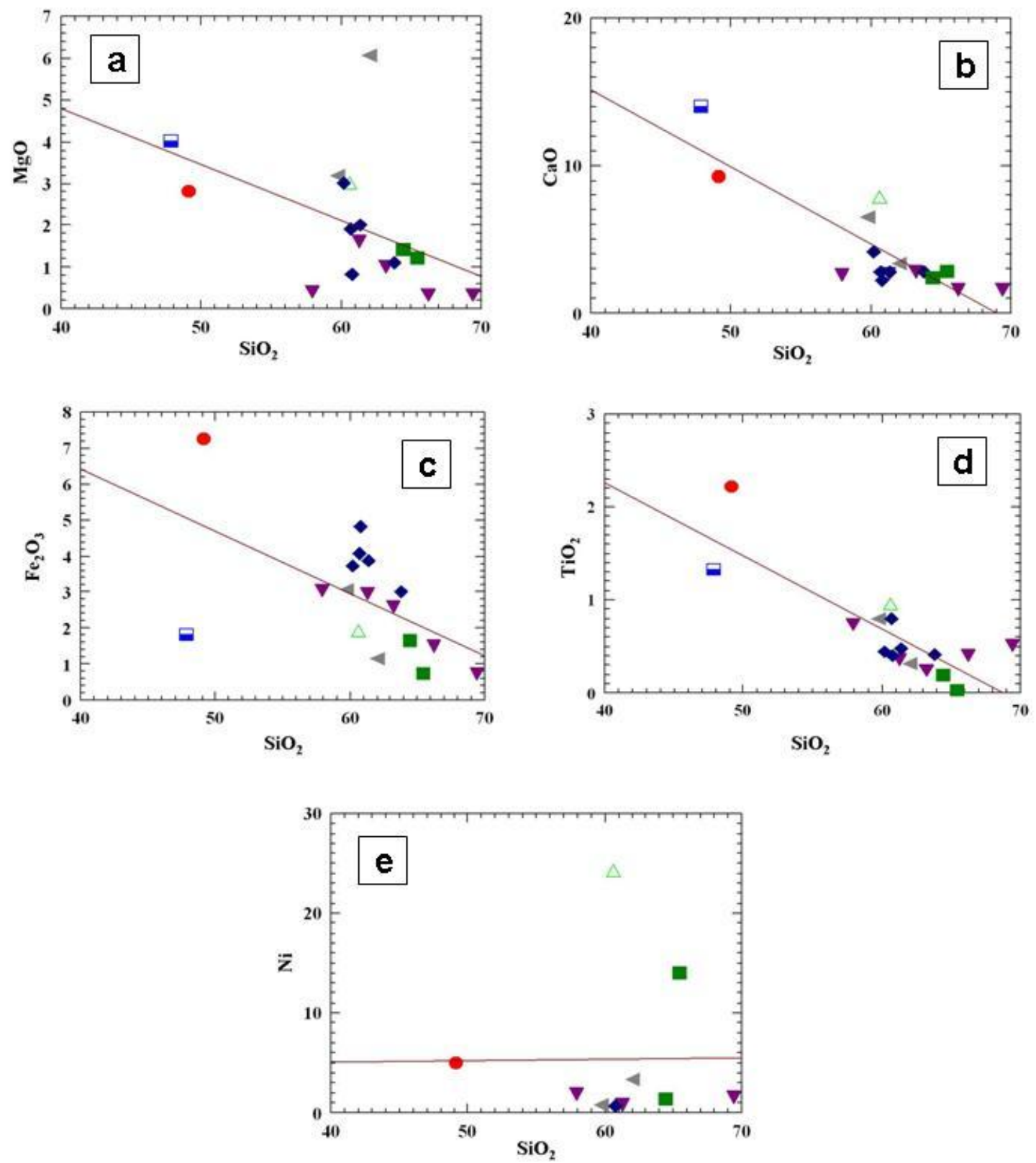

Fig. 6 Harker type diagrams between $\mathrm{SiO}_{2}$ and (a) $\mathrm{MgO}$; (b) $\mathrm{CaO}$; (c) Total iron as $\mathrm{Fe}_{2} \mathrm{O}_{3}$; (d) $\mathrm{TiO}_{2}$; (e) $\mathrm{Ni}$.

The plotted trends are visual estimates. Symbols as in Fig. 4.

to olivine and or pyroxene, would rapidly deplete $\mathrm{Al}$ relative to alkalis and promote the passage to peralkaline residual liquids.

The examination of the composition trends in the rocks of El-Kahfa complex is illustrated by $\mathrm{SiO}_{2}-\mathrm{Al}_{2} \mathrm{O}_{3}-\left(\mathrm{Na}_{2} \mathrm{O}+\mathrm{K}_{2} \mathrm{O}\right)$ ternary diagram of Bailey and MacDonald [44]. El-Kahfa rocks are plotted on the Al side following the metaluminous-peralkaline trend from the silica apex to the feldspar point (Fig. 7c), suggesting feldspar fractionation. MacDonald [43] referred that the development of peralkaline residue is possible in any suite where feldspar is fractionating and where there is a deficiency of $\mathrm{Al}_{2} \mathrm{O}_{3}$ (expressed as normative diopside and/or wallastonite). Woolley and Jones [45] added that the differentiation towards more peralkaline composition, almost certainly by alkalifeldspar fractionation (the plagioclase effect) as no other crystallizing phase would enhance the alkali-to-alumina ratio in liquid.

Mg-numbers in El-Kahfa rocks show distinctive 

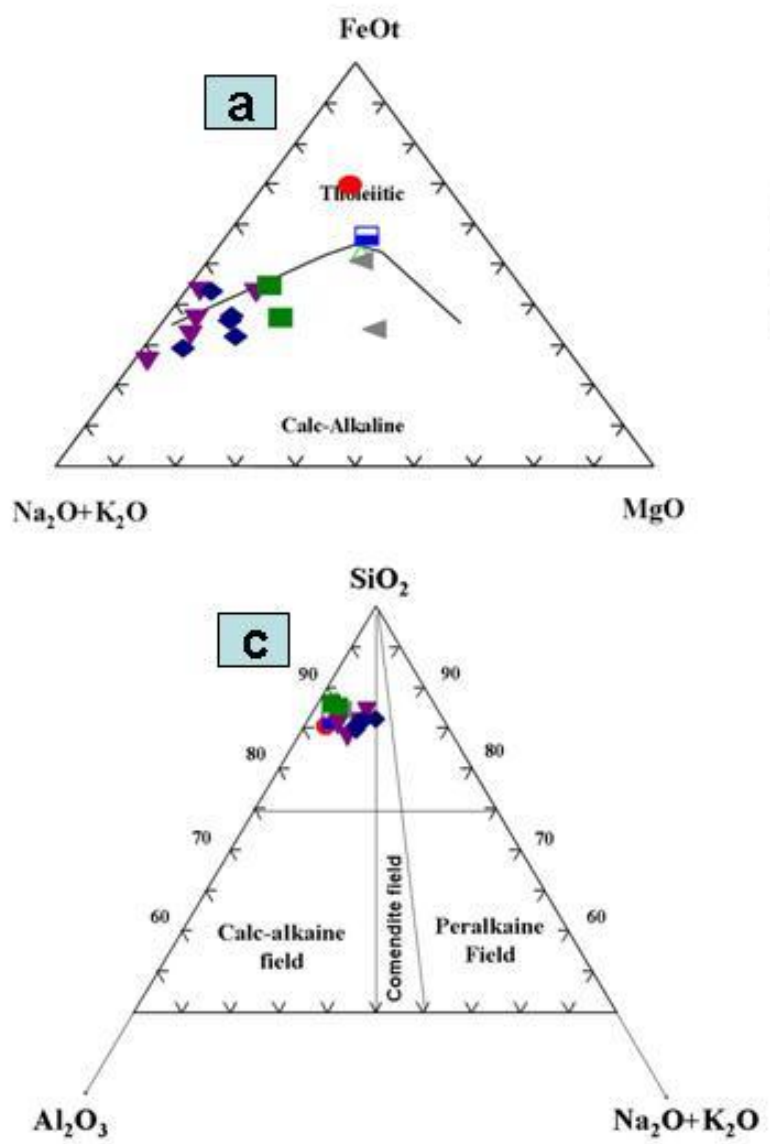
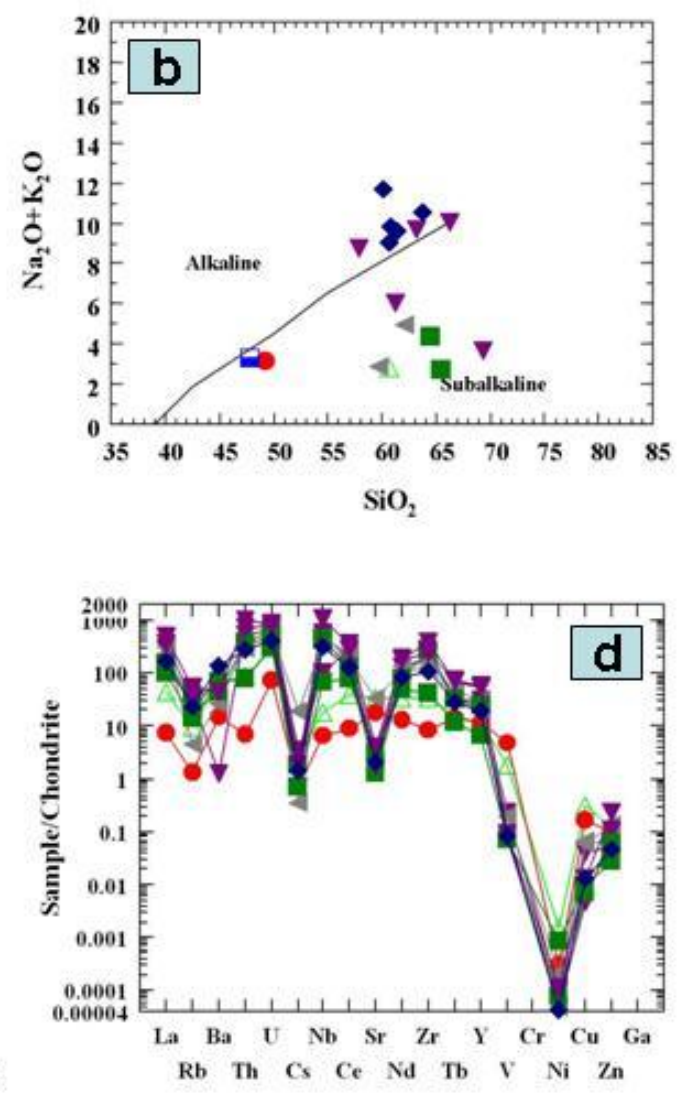

Fig. 7 (a) AFM diagram (Wager and Deer [46] and Irvine and Baragar [42]); (b) $\mathrm{SiO}_{2}$ - total alkalis diagram of Irvine and Baragar [42]; (c) $\mathrm{SiO}_{2}-\mathrm{Al}_{2} \mathrm{O}_{3}-\left(\mathrm{Na}_{2} \mathrm{O}+\mathrm{K}_{2} \mathrm{O}\right)$ diagram (Bailey and MacDonald [44]); (d) Spider diagram of trace elements. Symbols as in Fig. 4.

differentiation from basic to the high evolved varieties. The lower Mg-number values $(<30)$ of the sialic varieties are consistent with the pronounced fractionation of mafic minerals and feldspars [47].

Corundum occurrence in some syenite and trachyte norms is probably due to the loss of alkalis resulting from the action of magmatic fluids during their emplacement [48]. The appearance of acmite (Ac) and sodium meta-silicate (Ms) in two syenites and one trachyte sample, can be a characteristic trait of alkaline-peralkaline rocks [21].

El-Kahfa syenites and trachytes are enriched in LILE, $\mathrm{Rb}$ and $\mathrm{Ba}$ between 10 to more than 700 times against primitive mantle (Fig. 7d). The high concentration of these incompatible elements and their enhanced concentration in the felsic members by fractionation are typical of continental alkaline complexes [49]. The notable increase of $\operatorname{HFSE}(\mathrm{Nb}, \mathrm{Zr}$ and $\mathrm{Y}$ ) in these rock varieties can also be comparable with the within-plate basic sodic magma $[41,50]$.

The obvious increase in the HFSE ( $\mathrm{Zr}, \mathrm{Hf}$, Ta and $\mathrm{Nb}$ ) can be attributed to the fractionation of feldspars, pyroxenes and magnetite [51-54] mentioned that the high content of volatiles in the late stage of alkali magma differentiation leads to a decrease in the polymerization of magma and subsequent concentration of elements such as $\mathrm{Zr}, \mathrm{Nb}$, Ta and $\mathrm{Hf}$.

$\mathrm{Zr} / \mathrm{Nb}$ ratio (Fig. 8a) declares that El-Kahfa complex rocks appear to be related to their parental alkali-basaltic magma by crystal fractionation. Weaver et al. [55] and Baker [56] referred that in bimodal series $\mathrm{Zr} / \mathrm{Nb}$ ratio has been used to argue that the mafic and salic members are co-magmatic and related by crystal-liquid fractionation. 
On the $\mathrm{Nb} / \mathrm{Y}$ versus $\mathrm{Zr} / \mathrm{TiO}_{2} * 0.0001$ classification diagram of Winchester and Floyed [57] (Fig. 8b), El-Kahfa syenites and trachytes plot in the trachyte field, whereas the epidiorite and alkali-gabbro in the andesite and sub-alkaline basalt fields respectively.

Using the trace elements $\mathrm{Hf} / 3$-Th-Ta diagram of Wood [58] (Fig. 8c), shows that El Kahfa syenites and trachytes are affiliated to the alkaline within-plate basalts, whereas epidiorite is close to the volcanic arc

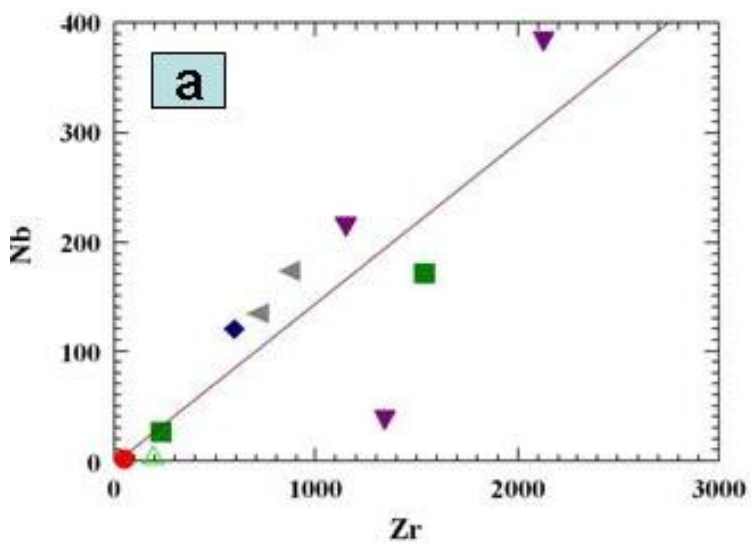

$\mathrm{Hf} / 3$

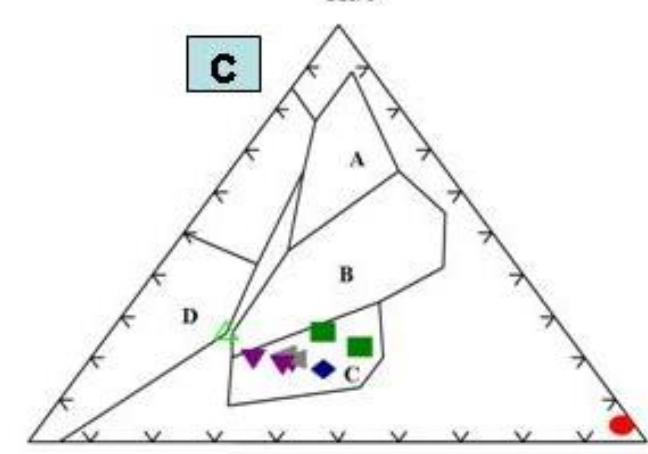

Th

Ta basalts.

The within-plate tectonic setting of the syenites and trachytes are confirmed on the $\mathrm{Nb}-\mathrm{Y}$ diagram (Fig. 8d) of Pearce et al. [59], while the alkali-gabbro and epidiorite are related to volcanic arc granites and the syn-collision granites.

\subsection{REEs (Rare Earth Elements)}

On the primitive-mantle normalized REE pattern
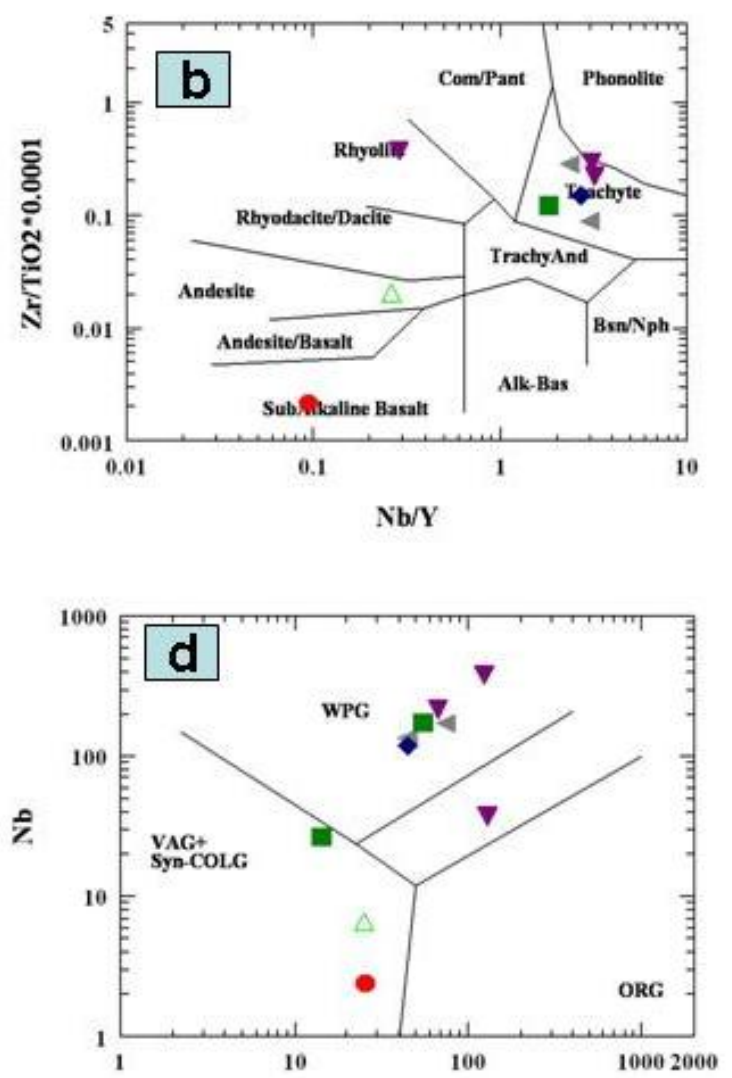

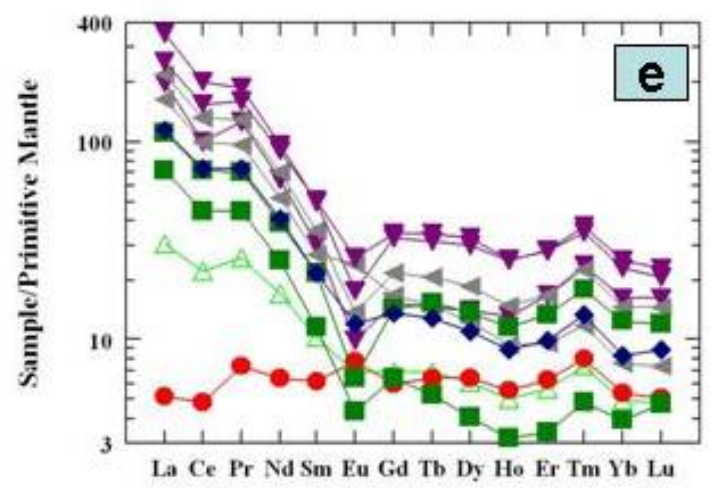

Fig. 8 (a) $\mathrm{Zr}$-Nb variation diagram. The plotted trend is visual estimate; (b) $\mathrm{Nb} / \mathrm{Y}-\mathrm{Zr} / \mathrm{TiO}_{2} * 0.0001$ classification diagram of Winchester and Floyd [57]); (c) Hf/3-Th-Ta diagram of Wood [58]; (d) Nb-Y variation diagram of Pearce et al. [59]; (e) Primitive mantle normalized REE pattern. Symbols as in Fig. 4. 
Table 3 Rare earth elements (ppm) and some ratios of El-Kahfa ring complex.

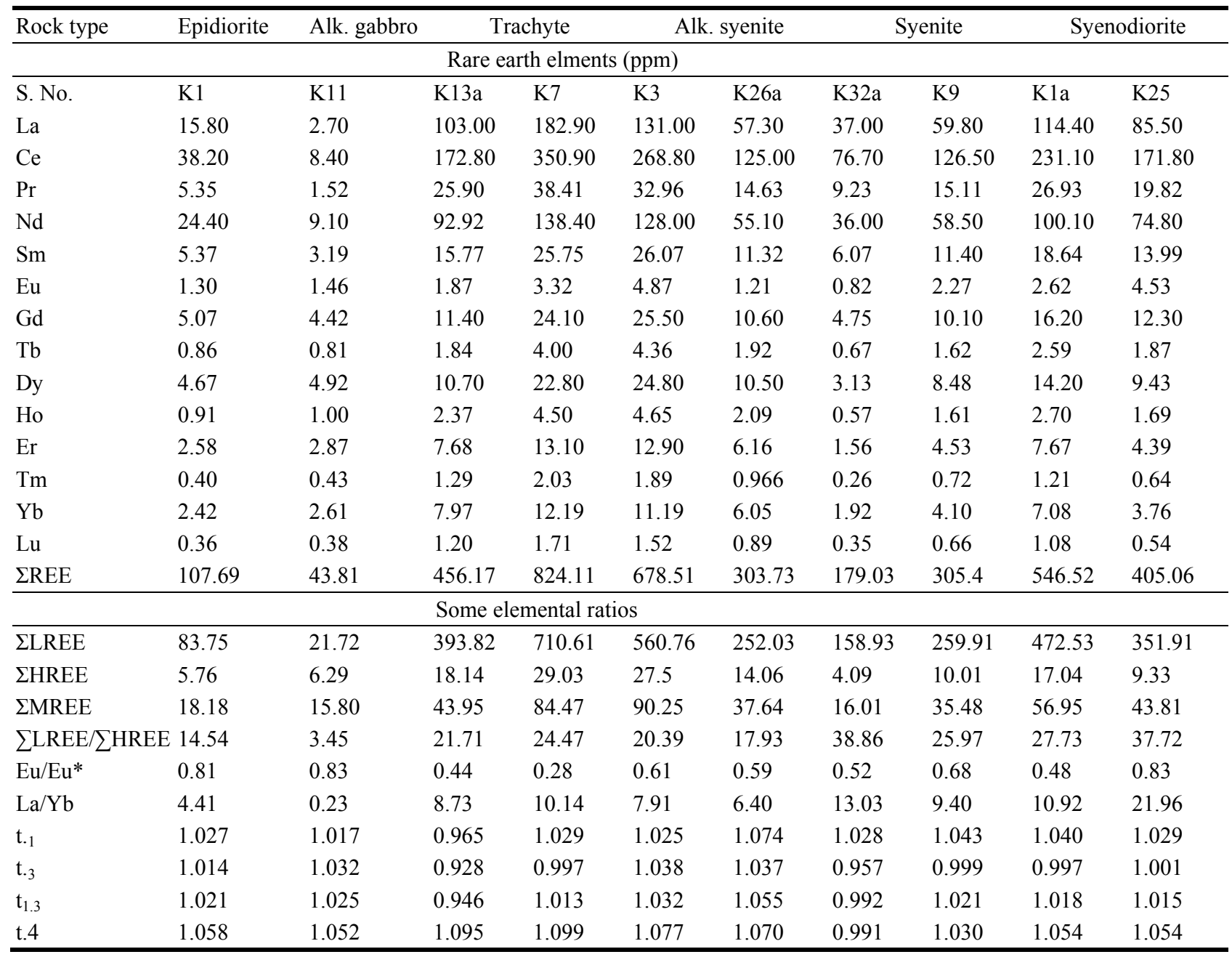

(Fig. 8e), and from Table 3, all of syenites and trachytes samples are enriched in LREE where $\sum$ LREE/ $\sum$ HREE for syenites range from 17.93 to 38.86 and 20.39 to 24.47 in trachytes respectively. They exhibit negative Eu anomalies attributed to the breakdown of their $\mathrm{Ca}$ minerals, where $\mathrm{Eu} / \mathrm{Eu}^{*}$ for syenites varies from 0.48 to 0.68 and for trachytes from 0.44 to 0.61 with $(\mathrm{La} / \mathrm{Yb}) n$ values which are positive. The epidiorites are less enriched in LREE (83.75), while the alkali-gabbro is relatively poor in LREE (21.72) and exhibit relative positive anomalies with $\mathrm{Eu} / \mathrm{Eu}^{*} 0.83$ and 0.81 respectively. The high percentages of $\mathrm{Sr}$ in the alkali gabbro samples with positive Eu anomalies can refer to their enrichment with plagioclases, which is confirmed from the petrography.
The pronounced feature that potentially influences the distribution of the REEs in most studied samples is the obvious lanthanide tetrad effect in all individual tetrad segments (Table 3 ) and Fig. 8e. The tetrad effect has progressively recognized particularly for all the rocks in studied ring which have undergone high degree of fractional crystallization $[52,60]$.

Monecke et al. [61] argued that the tetrad effect was either a feature of the magma-fluid system before magmatic crystallization or which the tetrad effect in the whole rock samples was inherited from external fluid during or after the emplacement of the magma.

\section{Radioactivity}

A total number of 10 rock samples representing the gabbro, syenite as well as trachyte were analyzed to 

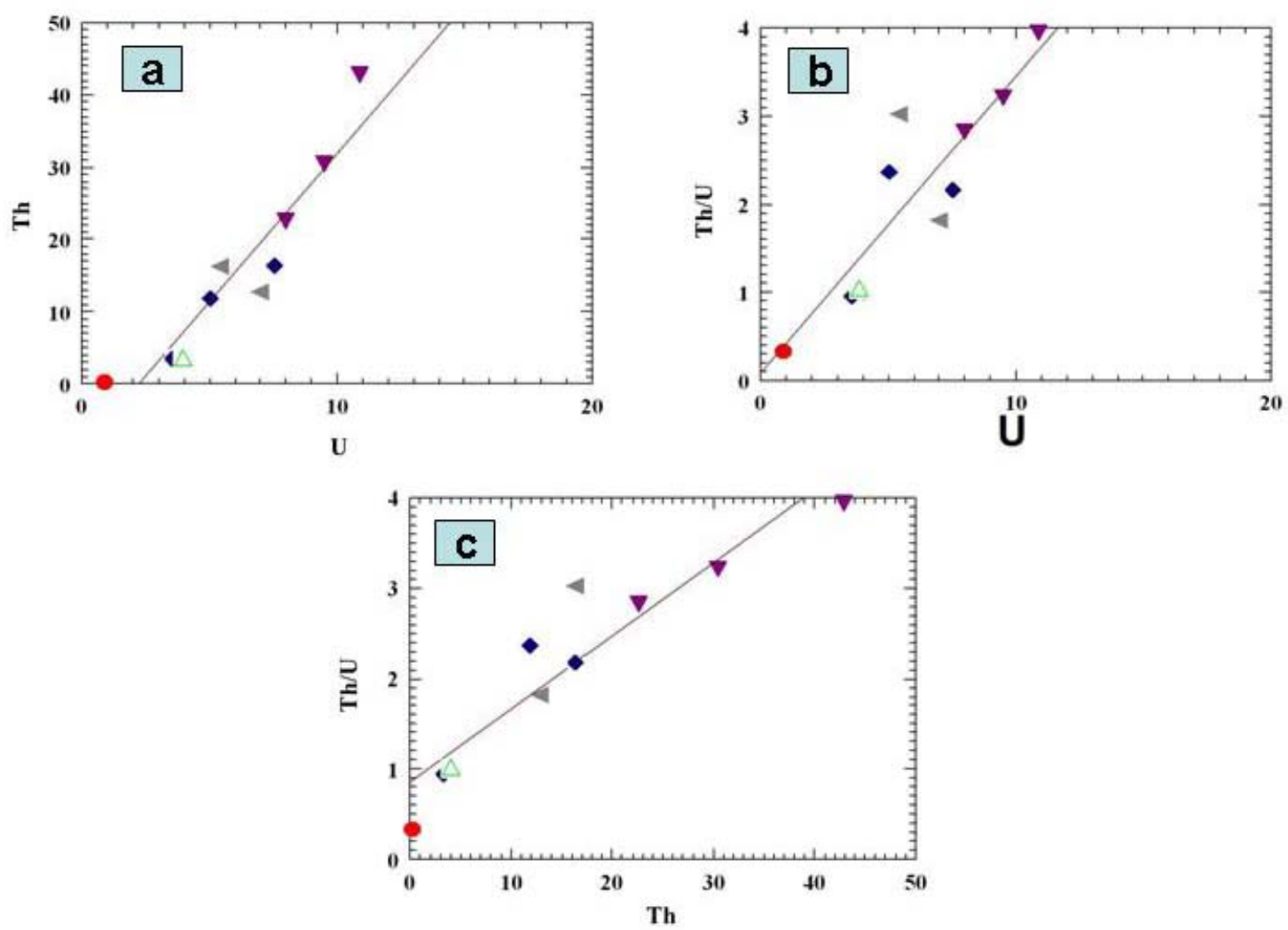

Fig. 9 (a) U-Th variation diagram (b) U-Th/U variation diagram (c) Th-Th/U variation diagram. The plotted trends are visual estimates. Symbols as in Fig. 4.

study the distribution of uranium and thorium (Table 2).

The geochemical behavior of $U$ and Th within the studied rock samples are investigated by plotting their contents as well as $\mathrm{Th} / \mathrm{U}$ ratios on variation diagrams. The $\mathrm{U}$ versus Th diagram (Fig. 9a) shows positive correlation and increasing trend from gabbro, syenite to the trachytic samples. The variation diagram between $\mathrm{U}$ content versus $\mathrm{Th} / \mathrm{U}$ ratio (Fig. 9b) clears that the studied rock samples fall along increasing trend from gabbro to syenite and trachyte indicating enrichment in $\mathrm{U}$ content relative to $\mathrm{Th}$ in the trachytic samples. Moreover, the increasing trend observed on Th versus $\mathrm{Th} / \mathrm{U}$ diagram (Fig. 9c) is attributed to some depletion in Th more than U. From the mentioned relationships, the trachytic samples are relatively enriched in both $\mathrm{U}$ and Th which can be attributed to the existence of $U$ and Th only within the resistate accessory minerals such as zircon, sphene, allanite, apatite, epidote and iron oxides which control the fractionation of $\mathrm{U}$ and $\mathrm{Th}$ in the studied rocks of El-Kahfa area.

\section{Discussion}

The general constant $\mathrm{Zr} / \mathrm{Nb}$ ratios in El-Kahfa rocks (Fig. 8a), and the constant $\mathrm{Sr} / \mathrm{Rb}$ ratios in the trachyte and syenite (Table 2) imply similar bulk distribution co-efficient (D-values) for these element pairs, which are related to fractionating mineral assemblages. Zhao et al. [52] referred that these constant ratios reflect the compositions of the parental magma and trend to mitigate against wall rock assimilation having played a significant role.

Bailey [62] and Woolley and Jones [45] explained the bimodality with the occurrence of large volumes of felsic rocks in Shilwa alkaline complex province, Malawi, and other alkaline provinces by a model for the generation of syenitic and more evolved felsic magmas include parental melting of metasomatized 
upper mantle. Bailey [62] noticed on the basis of experimental data that felsic minerals are stable up to 30 kbar, implying the possibility of felsic melt generation in the upper mantle. He proposed that a combination of volatile flux and well percolation along geotherms melt along geotherms that intersect the solidus at depths less than $80 \mathrm{Km}$ would lead to enrichment and metasomatism providing distinct mantle sources for felsic magmas. This model explains the large LREE/HREE ratios commonly observed in the voluminous felsic alkaline suites, which implies a garnet bearing source and the intimate association of both Si-saturated and Si-undersaturated phases.

The relatively low $\mathrm{Pb}$ contents (Table 2) in El-Kahfa syenites compared with that mentioned by Geramovsky [63] for different types of syenites are consistent with a strictly mantle derived magma, since mantle derived magmas contain only minor $\mathrm{Pb}$ contents [64].

$\mathrm{MgO}$ is generally high in El-Kahfa syenites (Table 1) (average of $\mathrm{MgO}$ is 0.96 of the alkali syenites after Nockods [65] for their parental magma to be derived directly by crystal fractionation of an alkali-basalt magma, where syenites known to be derived by fractionation of alkali-basalt magmas usually have much lower $\mathrm{MgO}$ [66-68, 52]).

Zhao et al. [52] concluded that mixing with crustal melt combined with minor crystal fractionation of mafic minerals is a more plausible model for the generation of the meta-syenitic magma from an initial mantle derived alkali-basaltic melt.

Alkaline magmas can be generated in almost all tectonic settings. The alkaline suites formed in subduction related magmas or those derived from a source which has been previously modified by subduction processes, usually show a distinctive negative $\mathrm{Nb}$ anomaly on the trace-element spider diagrams (e.g. [69, 70]), whereas those from continental rift zones or oceanic island settings display no or slightly positive $\mathrm{Nb}$ anomalies (e.g. [71, 72]).

Subduction related potassic alkaline magmas are considered to be derived from metasomatized mantle wedges above the deepest part of the subduction zone $[56,73]$, or the subcontinental lithospheric mantle which has been previously modified by subduction processes [69]. In either case, metasomatic phlogopite was considered to have been present in the source region, but not necessarily residual during partial melting [70, 73, 74]. In contrast, the rift- or hot spot-related alkaline magmas are interpreted as being related to garnet-present low-degree partial melting of upwelling asthenosphere mantle induced by lithospheric thinning or plume activities $[72,75]$.

Therefore, the parental magma of El Kahfa complex was probably derived from an $\mathrm{Nb}$ enriched or at least under-plated mantle source within the continental East-Africa rift zone.

\section{Summary and Conclusions}

El-Kahfa complex locates at the intersection of Lat. $24^{\circ} 8^{\prime} 18^{\prime \prime} \mathrm{N}$ and Long. 34 $38^{\prime} 55^{\prime \prime}$ E, South Eastern Desert, Egypt. It comprises an outer ring composed of alkaline syenites, ranging from barren- to quartz-bearing syenites, an inner ring varied in composition from leucocratic to melanocratic syenites, and a central stock formed essentially of alkali gabbros. These alkali gabbros are cut by small bodies of alkaline syenites, which occasionally grade into nepheline syenites. The country rocks are represented mainly by metavolcanics and epidiorites. El-Kahfa syenites lack any primary hydrous mafic silicates, indicating that their magma was anhydrous.

Rock classifications refer that the syenites and trachytes are in the trachyte fields, the syenodiorites and epidiorites affiliate mostly the trachyandesites, whereas alkali gabbros are in the basalt field.

Geochemically, the overall decrease in $\mathrm{MgO}, \mathrm{CaO}$, $\mathrm{FeO}^{\mathrm{t}}$ and $\mathrm{TiO}_{2}$ against $\mathrm{SiO}_{2}$ can reflect the crystallization of early plagioclase followed by $\mathrm{Fe}-\mathrm{Ti}$ oxides minerals and finally alkali feldspars. The variably high $\mathrm{MgO}, \mathrm{FeO}^{t}$ and $\mathrm{Ni}$ in the alkali basalts and alkali gabbros are consistent with their derivation 
evolved from mantle melts.

The differentiation trend of rock alkalinity from peraluminous towards more peralkaline composition can certainly be due to alkali feldspar fractionation (the plagioclase effect).

The affiliation of El-Kahfa complex to the continental and within-plate alkaline complexes is clear through the enrichment of the complex rocks in the LILE ( $\mathrm{Rb}$ and $\mathrm{Ba}$ ) and the HFSE ( $\mathrm{Zr}, \mathrm{Hf}$, Ta and $\mathrm{Nb}$ ) through their differentiation process from a basic sodic magma.

$\mathrm{Zr} / \mathrm{Nb}$ ratio declares also that El-Kahfa complex rocks are related to their parental alkali-basalt magma by crystal fractionation. The bimodal character of this ratio shows that the mafic and salic members in this complex are co-magmatic and related by crystal-liquid fractionation.

On the primitive-mantle normalized pattern, the tetrad effects in the lanthanides are obvious in El-Kahfa rocks. They are represented mainly with the M-type in the more evolved rocks. These tetrad effects are either a feature of the magma-fluid system before magmatic crystallization, or inherited from external fluid during or after the emplacement of the magma.

As a conclusion El-Kahfa rocks parental magma was probably derived from an $\mathrm{Nb}$-enriched or at least under-plate mantle source within the continental East-Africa rift zone. This magma can be subjected to minor crustal contamination through their fractional crystallization.

The radiometric study of El-Kahfa rocks revealed that the trachytic samples are relatively enriched in both $\mathrm{U}$ and $\mathrm{Th}$ and this is attributed to the existence of $\mathrm{U}$ and Th only within the resistant accessory minerals such as zircon, sphene, allanite, apatite, epidote and iron oxides which control the fractionation of $U$ and Th.

\section{References}

[1] Hunting Geology and Geophysics Ltd. 1967. "Assessment of the Mineral Potential of Aswan Region, U.A.R.” UNDP and Regional Planning of Aswan.
[2] Lockwood Survey Corporation Ltd. 1968. Airborne Magnetometer, Scintillation Counter, Dual Frequency Electro Magnetometer Survey of a Part of the Aswan Region, U.A.R. Report on subcontract by the United Nation Development Programme, Toronto, Canada, 178.

[3] El-Ramly, M. F., Budanov, V. L., Armanious, L. K., and Dereniuk, N. E. 1969. "The Three Ring Complexes of Gabal El Kahfa, Gabal Nigrub El-Fogani and Gabal El-Naga." Geol. Surv. Egy.: 52.

[4] El-Ramly, M. F., Budanov, V. L., and Hussein, A. A. 1971. "The Alkaline Rocks of South-Eastern Egypt." Geol. Surv. Egy.: 53.

[5] El-Ramly, M. F., and Hussein, A. A. 1982. "The Alkaline Ring Complexes of Egypt." Geol. Surv. Egy.: 63.

[6] El-Ramly, M. F., and Hussein, A. A. 1985. "The Ring Complexes of the Eastern Desert of Egypt." Jour. Afr. Earth Sci. 3 (1-2): 77-82.

[7] El-Ramly, M. F. 1972. "A New Geological Map for the Basement Rocks in the Eastern and South Western Deserts of Egypt, Scale 1:1,000,000.” Ann. Geol. Surv. Egy. II: $1-18$.

[8] Garson, M. S., and Krs, M. 1976. "Geophysical and Geological Evidence of the Relationship of Red Sea Transverse Tectonics to Ancient Features." Bull. Geol. Soc. Am. 87: 169-81.

[9] Serenesites, C. Mc.C., Faul, H., Foland, K. A., El-Ramly, M. F., and Hussein, A. A. 1979. "Alkaline Ring Complexes in Egypt: Their Ages and Relationship to Tectonic Development of the Red Sea." Ann. Geol. Surv. Egy. IX: 102-16.

[10] Hashad, A. H., and El-Reedy, M. W. M. 1979. "Geochronology of the Anorogenic Alkaline Rocks, South-Eastern Desert Egypt.” Ann. Geol. Surv. Egypt 9: 81-101.

[11] Hohndorf, A., Meinhold, K. D., and Vail, J. R. 1994. "Geochronology of Anorogenic Igneous Complexes in the Sudan: Isotopic Investigations in the North Kordofan, the Nubian Desert and Red Sea Hills.” Jour. Afr. Earth Sci. 19 (112): 3-15.

[12] Vail, J. R. 1989. "Ring Complexes and Related Rocks in Africa." Jour. Afr. Earth Sci. 8 (1): 19-40.

[13] Razvalyayev, A. V., and Shakhov, G. P. 1976. "New Data on Ring Intrusions of the Red Sea Rift Zone." Doklady Akad. Nauk SSSR 229: 947-50.

[14] Razvalyayev, A. V., and Shakhov, G. P. 1978. "Tectonic Significance of Location of Some Tectonic Ring Complexes in the Red Sea Rift Zone (in Russian)." Bull. Moscow Soc. Trans Geol. Sect. 53 (2): 56-66.

[15] Abdel Khalek, M. L., Abdel Maksoud, M. A., Sabet, A. H., and Owess, K. A. 1988a. "Geochemistry of El-Kahfa Ring Complex, Eastern Desert, Egypt.” Bull. Fac. Sci., Cairo Univ. 56: 645-69. 
[16] Abdel Khalek, M. L., Abdel Maksoud, M. A., Sabet, A. H., and Owess, K. A. 1988b. "Geologic Setting and Petrography of El-Kahfa Ring Complex, Eastern Desert, Egypt.” Bull. Fac. Sci., Cairo Univ. 56: 721-55.

[17] Ragab, A. A., Moussa, E. M., and Asran, H. M. 2007. "Geochemistry and Petrogenesis of Alkaline Syenite from Some Ring Complexes in the South Eastern Desert, Egypt." The Fifth International Conf. on the Geology of Africa 1: 43-61.

[18] Bonin, B. 1986. Ring Complex Granites and Anorogenic Magmatism. London: North Oxford Academic Pub.

[19] Sorensen, H. 1974. "Alkali Syenites, Feldspathoidal Syenites and Related Lavas." In The Alkaline Rocks, edited by Sorensen, H. New York: John Wiley \& Sons, 22-52.

[20] Le Maitre, R. W. 1989. A Classification of Igneous Rocks and Glossary of Terms. Oxford: Blackwell.

[21] Madhavan, V., Mallikharjuna, Rao J., Srinivas, M., Natarajan, R., and Ausaf Syeed. 1994. "Petrology and Petrogenesis of Syenites from the Cuddapah Basin, Andhra Pradesh.” Jour. Geol. Soc. India 43: 225-37.

[22] Wilkinson, J. F. G., and Le Maitre, R. W. 1987. "Upper Mantle Amphiboles and Micas and $\mathrm{TiO}_{2}, \mathrm{~K}_{2} \mathrm{O}$ and $\mathrm{P}_{2} \mathrm{O}_{5}$ Abundances and $100 \mathrm{Mg} /\left(\mathrm{Mg}^{+} \mathrm{Fe}^{2+}\right)$ Ratios of Common Basalts and Andesites: Implications for Modal Mantle Metasomatism and Undepleted Mantle Compositions." Jour. Petrol. 28: 37-73.

[23] Yagi, K. 1953. "Petrochemical Studies on the Alkalic Rocks of the Morotu District, Sakhaline." Bull. Geol. Soc. Am. 64: 769-810.

[24] Huckenholz, H. Z. 1965. "Der petrobenestsche wedegang der klinopyroens in denteriarent vulkaniten der HoheifelIII. Die klinopyroxene der Pikribasalte (Ankaranite)." Beitr. Miner. Petrg. 12: 73-95.

[25] Wilkinson, J. F. G. 1966. "Clinopyroxenes from the Square Top Intrusion, Nundle, New South Wales." Mineral. Mag. 35: 1061-70.

[26] Eggleton, R. A. 1975. "Nontronite Topotaxial after Hedenbergite." Am. Min. 60: 1063-8.

[27] Shapiro, L., and Brannock, W. W. 1962. "Rapid Analysis of Silicate, Carbonate and Phosphate Rocks." Bull. U.S. Geol. Surv. 1144 (A): 56.

[28] El-Reedy, M. W. 1984. The General Physical and Chemical Features and the Pollution Level of El-Sabahia-Sabhan El-Reqa Soil Localities (Part I: Chemical Methods). State of Kuwait, report presented to Environmental Protection Dept., Ministry of Public Health, Kuwait.

[29] Bryan, W. B. 1964. "Relative Abundances of Intermediate Members of the Oceanic Basalt-Trachyte Association: Evidence from Clareon and Socotto Island, Revillagigedo Island.” Mexico Jour. Geophys. Res. 69: 3047-9.
[30] Le Maitre, R. W. 1968. "Chemical Variation within and between Volcanic Rock Series: A Statistical Approach." Jour. Petrol. 9: 220-52.

[31] MacDonald, R. 1987. "The Quaternary Peralkaline Silicic Rocks and Caldera Volcanoes of Kenya." In Alkaline Igneous Rocks, edited by Fitton, J. G., and Upton, B. G. J. Geol. Soc. Spec. Publ. 30: 381-401.

[32] Baker, B. H., Goles, G. G., Leeman, W. P., and Lindstrom, M. M. 1977. "Geochemistry and Petrogenesis of Basalt-Benmoreite-Trachyte Suite from the Southern Part of the Gregory Rift. Kenya." Contr. Miner. Petrol. 64: 303-32.

[33] Jones, W. B. 1979. "Mixed Benmorreit/Trachyte Flows from Kenya and Their Bearing on the Daly Gap." Geol. Mag. 116: 487-9.

[34] Weaver, S. D. 1978. "The Quaternary Caldera Volcano Emuruangogolak, Kenya Rift, and the Petrology of a Bimodal Ferrobasalt-Pantelleritic Trachyte Association.” Bull. Volc. 40: 209-30.

[35] Clague, D. A. 1987. "Hawaiin Alkaline Volcanism." In Alkaline Igneous Rocks, edited by Fitton, J. G., and Upton, B. G. J. Geol. Soc. Spec. Publ. 30: 227-52.

[36] Gasparon, M., Innocenti, F., Manett, P., Peccerillo, A., and Tsegaye, A. 1993. "Genesis of the Pliocene to Recent Bimodal Mafic-Felsic Volcanism in the Debre Zeyt Area, Central Ethiopia: Volcanological and Geochemical Constraints." Jour. Afric. Earth Sci. 17 (2): 145-65.

[37] Bishady, A. M. 1995. "Petrography and Geochemistry of the Two Ring Complexes El-Gezira and Mansouri, South Eastern Desert, Egypt.” Sci. Jour. Fac. Sci. Menoufia Univ. XI: 221-75.

[38] Norry, M. J., Truckle, P. H., Lippard, S. J., Hawkesworth, C. J., Weaver, S. D., and Narriner, G. F. 1980. "Isotopic and Trace Element Evidence from Lava, Bearing on Mantle Heterogeneity Beneath Kenya." Phil. Trans. R. Soc. Lond. Ser. A 297: 259-71.

[39] Streckeisen, A. 1976. "To Each Plutonic Rock Its Proper Name.” Earth Sci. Rev. 12: 1-33.

[40] Bonin, B., and Lameyre, J. 1978. "Reflexions sur la position et L'origin des complexes magmatique anorogèniques.” Bull. Soc. Géol. Fr. 20: 45-59.

[41] Bhattacharya, S., and Rajib Kar. 2005. "Petrological and Geochemical Constraints on the Evolution of the Alkaline Complex of Koraput in the Eastern Ghats Granulite Belt, India." Gondwana Research 8 (4): 596-602.

[42] Irvine, T. N., and Baragar, W. R. A. 1971. "A Guide to the Chemical Classification of the Common Volcanic Rocks." Can. Jour. Earth Sci. 8: 523-48.

[43] MacDonald, R. 1974. "The Role of Fractional Crystallization in the Formation of the Alkaline Rocks." In The alkaline Rocks, edited by Sorensen. NY: John Willy \& Sons, 442-59. 
[44] Bailey, D. K., and MacDonald, R. 1969. “Alkali Feldspar Fractionation Trends and the Derivation of Peralkaline Liquids." Am. Jour. Sci. 267: 242-8.

[45] Woolley, A. R., and Jones, G. C. 1987. "The Petrochemistry of the Northern Part of the Chilwa Alkaline Provine, Malawi." In Alkaline Igneous Rocks, edited by Fitton, J. G., and Upton, B. G. J. Geol. Soc. Spec. Publ. 30: 335-55.

[46] Wager, L. R., and Deer, W. A. 1939. "Geological Investigations in East Greenland, Part III: The Petrology of the Skaergaard Intrusion, Kangerdlussuaq, East Greenland." Med. Om. Graland 105: 1-352.

[47] Sheraton, J. W., Black, L. P., and Tindle, A. G. 1992. "Petrogenesis of Plutonic Rocks in a Proterozoic Granulite Facies Terrane-The Bunger Hills, East Antractica." Chem. Geol. 97: 163-98.

[48] Lubala, R. T., Frick, C., Rogers, J. H., and Waltaven, F. 1994. "Petrogenesis of Syenites and Granites of the Schiel Alkaline Complex, Northern Transvaal South Africa." Jour. Geol. 102: 307-16.

[49] Philpots, A. R. 1990. Principles of Igneous and Metamorphic Petrology. New Jersey: Prentic Hall.

[50] Sun, S. S., and McDonough, W. F. 1989. "Chemical and Isotopic Systematics of Oceanic Basalts: Implications for Mantle Composition and Processes." In Magmatism in Ocean Basins, edited by Saunders, A. D., and Norry, M. J. Geol. Soc. London, Spec. Pub.: 313-45.

[51] Curri, K. L., Eby, G. N., and Gittins, J. 1986. "The Petrology of the Mont Saint Hilaire Complex, Southern Quebec: An Alkaline Gabbro-Peralkaline Syenite Association." Lithos 10: 65-81.

[52] Zhao, J. X., Shiraishi, K., Ellis, D. J., and Sheraton, J. W. 1995. "Geochemical and Isotopic Studies of Syenites from the Yamato Mountains, East Antarctica: Implications for the Origin of Syenitic Magma." Geochim. et Cosmochim. Acta 59 (7): 1363-82.

[53] Taylor, S. R. 1965. "The Application of Trace Element Data to Problems in Petrology." Phys. Chem. Earth. 6: 133-213.

[54] Ringwood, A. E. 1955. "The Principles Govering Trace Element Behavior during Magmatic Crystallization. Part. II, The Role of Complex Formation." Geocheim. et Cosmochim. Acta 7: 242-54.

[55] Weaver, S. D., Sceal, J. S. C., and Gibson, I. L. 1972. "Trace Element Data Relevant to the Origin of Trachytic and Pantelleritic Lava in the East Africa Rift System." Contrib. Mineral. Petrol. 36: 181-94.

[56] Baker, B. H. 1987. "Outline of the Petrology of the Kenya Rift Alkaline Province.” In Alkaline Igneous Rocks, edited by Fitton, J. G., and Upton, B. G. J. Geol. Soc. Spec. Publ. 30: 293-311.

[57] Winchester, J. A., and Floyd, P. A. 1977. "Geochemical
Magma Type Discrimination; Application to Altered and Metamorphosed Basic Igneous Rocks.” Earth Planet. Sci. Lett. 28: 459-69.

[58] Wood, D. A. 1980. "The Application of a Th-Hf-Ta Diagram to Problems of Tectonomagmatic Classification and to Establishing the Nature of Crustal Contamination of Basaltic Lavas of the British Tertiary Volcanic Province." Earth Planet. Sci. Lett. 50: 11-30.

[59] Pearce, J. A., Harris, N. B. W., and Tindle, A. G. 1984. "Trace Element Discrimination Diagrams for the Tectonic Interpretation of Granitic Rocks." Jour. Petrol. 25: 956-83.

[60] Irber, W. 1999. "The Lanthanide Tetrad Effect and Its Correlation with $\mathrm{K} / \mathrm{Rb}, \mathrm{Eu} / \mathrm{Eu}^{*}, \mathrm{Sr} / \mathrm{Eu}, \mathrm{Y} / \mathrm{Ho}$ and $\mathrm{Zr} / \mathrm{Hf}$ of Evolving Peraluminous Granite Suites." Geochim et Cosmochim. Acta 63 (3/4): 489-508.

[61] Monecke, T., Kempe, U., Monecke, J., Sala, M., and Wolf, D. 2002. "Tetrad Effect in Rare Earth Element Distribution Patterns: A Method of Quantification with Application to Rock and Mineral Samples from Granite-Related Rare Metal Deposits." Geochim. Et Cosmochim. Acta. 66 (7): 1185-96.

[62] Bailey, D. K. 1987. "Mantle Metasomatism-Perspective and Prospect." In Alkaline Igneous Rocks, edited by Fitton, J. G., and Upton, B. G. J. Geol. Soc. Spec. Publ. 30: 1-13.

[63] Gersimovsky, V. L. 1974. "Trace Elements in Selected Groups of Alkaline Rocks." In The alkaline Rocks, edited by Sdrensen, 402-12.

[64] Zartman, R. E., and Doe, B. R. 1981. "Plumbotectonics: The New Model.” Tectonophysics 71: 135-62.

[65] Nockolds, S. R. 1954. "Average Chemical Compositions of Some Igneous Rocks." Bull. Geol. Soc. Am. 65: 1007-32.

[66] Fisk, M. R., Upton, B. G. J., and Ford, C. E. 1988. "Geochemical and Experimental Study of the Genesis of Magmas of Reunion Island, Indian Ocean.” Jour. Geophys. Res. 93: 4933-50.

[67] Smith, I. E. M., White, A. J. R., Chappell, B. W., and Eggleton, R. A. 1988. "Fractionation in a Zoned Monzonite Pluton: Mount Dromedary, Southeastern Australia." Geol. Mag. 125: 273-84.

[68] Harris, C., and Grantham, G. H. 1993. "Geology and Petrogenesis of the Straumsvola Nepheline Syenite Complex, Dronning Maud Land, Antractica." Geol. Mag. 130: 513-32.

[69] Nelson, D. R., and McCulloch, M. T. 1989. "Enriched Mantle Components and Mantle Recycling of Sediments." In Kimberlites and Related Rocks, 1, Their Composition, Occurrence, Origin and Emplacement, edited by Ross, J. Geol. Soc. Aust. Spec. Publ. 14: 560-70.

[70] Rogers, N. W., Hawkesworth, C. J., Parker, R. J., and March, J. S. 1985. "The Geochemistry of Potassic Lavas 
from Vulsini, Central Italy, and Implications for Mantle Enrichment Processes beneath the Roman Region." Contr. Mineral. Petrol. 90: 244-57.

[71] Menzies, M. 1987. "Alkaline Rocks and Their Inclusions: A Window on the Earth's Interior." In Alkaline Igneous Rocks, edited by Fitton, J. G., and Upton, B. G. J. Geol. Soc. Spec. Publ. 30: 15-27.

[72] MacDonough, W. F., McCulloch, M. T., and Sun, S. S. 1985. "Isotope and Geochemical Systematics in Tertiary-Recent Basalts from South-Eastern Australia and Implications from the Evolution of the Sub-continental Lithosphere." Geochem. Cosmo. Acta 49: 2051-67.
[73] Wyllie, P. J., and Sekine, T. 1982. "The Formation of Mantle Phlogopite in Subduction Zone Hybridization." Contrib. Mineral. Petrol. 79: 375-80.

[74] Williams, R. W., Collerson, K. D., Gill, J. B., and Deniel, C. 1992. "High $\mathrm{Th} / \mathrm{U}$ Ratios in Subcontinental Lithospheric Mantle Mass Spectrometric Measurement of Th Isotopes in Gaussberg Lamproites." Earth Planet. Sci. Lett. III: 257-68.

[75] Fitton, J. G. 1987. “The Cameron Line, West Africa: A Comparison between Oceanic and Continental Alkaline Volcanism." In Alkaline Igneous Rocks, edited by Fitton, J. G., and Upton, B. G. J. Geol. Soc. Spec. Publ. 30: 273-91. 